\title{
Composites
}

\section{Cellulose acetate/sodium-activated natural bentonite clay nanofibres produced by free surface electrospinning}

\author{
Mohamed Basel Bazbouz ${ }^{1, *}$ (1) and Stephen J. Russell ${ }^{1}$ (B) \\ ${ }^{1}$ Textile Technology Research Group, School of Design, University of Leeds, Leeds LS2 9JT, UK
}

Received: 17 January 2018

Accepted: 19 April 2018

Published online:

26 April 2018

(C) The Author(s) 2018

\begin{abstract}
Incorporating activated bentonite clay (BC) into electrospun nanofibres is an established strategy for modulating adsorption behaviour. In the present study, naturally occurring calcium $\mathrm{BC}$ was completely activated to sodium $\mathrm{BC}$ with a 4 wt\% sodium carbonate $\left(\mathrm{Na}_{2} \mathrm{CO}_{3}\right) / \mathrm{BC}$ ratio. Composite nanofibre webs were produced from cellulose acetate (CA)/BC spinning solutions using free surface electrospinning, and the effect of $\mathrm{BC}$ loadings on viscosity, surface tension and electrical conductivity prior to spinning was studied. Chemical and thermal analyses were conducted on as-spun fibres, and SEM and TEM revealed a nanofibrous morphology consisting of an interpenetrating network of fibres and semi-spherical features resembling jellyfish with an internal core of BC.
\end{abstract}

\section{Introduction}

Electrospun polymer nanofibres have interesting characteristics resulting from their sub-micron diameter, fine interconnected porous network and high surface-to-weight ratio compared to other fibrous structures [1]. These characteristics promote enhanced surface reactivity and make nanofibres attractive for numerous applications such as air and liquid filtration [2], reinforced composites [3] and medical devices [4]. For most engineering and industrial applications of nanofibres, thermal stability and mechanical stability are normally required [5] and both can be addressed by incorporation of nanometre-sized components such as metallic

Address correspondence to E-mail: m.b.bazbouz@leeds.ac.uk nanoparticles [6], carbon nanotubes (CNTs) [7] and single or hybrid aluminous silicate clay fillers [8-51].

It has been demonstrated that electrospinning of polymer-clay composites with a small amount (1-10 wt $\%$ ) of clay filler can lead to remarkable improvements in wettability and swelling [42], mechanical properties, including Young's modulus [19, 24], thermal stability [49], flame retardancy [20], heat distortion temperature [45], UV resistance [25], chemical affinity [33] and gas barrier properties [40] compared to pure polymer nanofibres. BC, formed from weathering of volcanic ash in the presence of water, is an absorbent aluminium phyllosilicate clay consisting mostly of smectite [52]. Owing to its adsorptive and absorptive capabilities and cation exchange capacity, it has been applied in health care 
for a variety of purposes including wound healing and infection control [53-55], skin protection [56], cosmetics [57] and rheumatism treatment [58]. Moreover, BC has been applied in heavy metal ion adsorption [59] and removal of organic pollutants from water [60]. BC based on the dominant exchangeable cations present is referred to as either calcium, sodium or potassium bentonite [61, 62]. The smectite group such as montmorillonite (MMT) is the most dominant mineral in bentonite, representing up to $70-80 \%$ by weight, while other minerals in bentonite such as kaolinite and none-clay minerals make up to $20-30 \%$ [62]. Single or hybrid MMT with or without modification has been successfully synthesised and electrospun with different polymers. Table 1 summarises the electrospun nanofibres produced with single or hybrid MMT fillers and their proposed applications [8-51].

The incorporation of activated, natural BC in electrospun fibres has received substantially less attention than synthesised materials in the literature, particularly so using electrospinning methods that utilise free surface methods. Electrospinning is typically restricted to $0.1-1.0 \mathrm{~g} \mathrm{~h}^{-1}$ for a single spinneret [63], with a polymer solution throughput in the range of $0.1-10 \mathrm{ml} \mathrm{h}^{-1}$ [64]. To increase yield, numerous needle-free electrospinning approaches have been developed [65-67], some of which involve the rotation of a solid surface through a polymer solution. One example is the Nanospider ${ }^{\circledR}$ [68] in which the polymer solution is electrospun from either wirebased or roller electrodes, so that nanofibre production rate can be conveniently adjusted depending on the electrode width, the linear speed of the wires/ roller and the number of spinning heads placed in series $[66,68,69]$. Fibres with diameters in the range $50-500 \mathrm{~nm}$ can therefore be produced at a rate of about $1.5 \mathrm{~g} \mathrm{~min}^{-1}$ per meter of roller length [68].

Given the dearth of previous studies focusing on the preparation of nanofibres containing natural $\mathrm{BC}$, the purpose of this study is to determine the feasibility of delivering such composite fibres by means of high-speed, free surface electrospinning. In the present investigation, CA was selected as a carrier polymer because of its ease of solubility in organic solvents, chemical resistance and thermal stability [70, 71]. The chemical and physical properties of the resulting materials were also studied to understand the extent to which incorporation of the natural BC modulated behaviour.

\section{Materials and methods}

\section{Materials}

Cellulose acetate CA (39.8\% acetyl content, MW of $\left.30.000 \mathrm{~g}^{\text {mole }}{ }^{-1}\right)$, sodium carbonate $\left(\mathrm{Na}_{2} \mathrm{CO}_{3}\right)$, carboxymethyl cellulose (CMC), hydrochloric acid $(\mathrm{HCl})$ (reagent grade, 37\%), acetic acid $(\mathrm{AcOH})(99-100 \%)$ and sulphuric acid $\left(95-98 \% \mathrm{H}_{2} \mathrm{SO}_{4}\right)$ were purchased from Sigma-Aldrich (UK). Natural bentonite clay (Beloon) (BC) was collected during the dry season from Azaz, northwest of Aleppo, Syria (latitude: $36^{\circ} 35^{\prime} 11^{\prime \prime} \mathrm{N}$, longitude: $37^{\circ} 02^{\prime} 46^{\prime \prime} \mathrm{E}$ ).

\section{BC purification and activation}

BC was initially dried in ambient conditions, followed by oven drying at $100{ }^{\circ} \mathrm{C}$ for $24 \mathrm{~h}$ to remove moisture from the clay. Dried BC was crushed, ground and sieved using a $63-\mu \mathrm{m}$ mesh. Purification of BC involved immersing $100 \mathrm{~g}$ of $\mathrm{BC}$ in $200 \mathrm{ml}$ of $1.6 \mathrm{M} \mathrm{HCl}$ and stirring for $4 \mathrm{~h}$ at $100 \mathrm{r} \mathrm{min}^{-1}$; then, the $\mathrm{BC}$ was filtered and washed in distilled water. The resulting purified $\mathrm{BC}$ was heated and dried at a temperature of $100{ }^{\circ} \mathrm{C}$ for $6 \mathrm{~h}$. In order to activate the purified BC with sodium $\mathrm{Na}^{+}$(referred to as ${ }^{~} \mathrm{Na}^{+}$ sodium ion exchange activation'), 4 wt $\%$ of $\mathrm{Na}_{2} \mathrm{CO}_{3}$ was added to the $\mathrm{BC}$ and stirred for $2 \mathrm{~h}$ to allow for both sodium ion exchange and water to remove the exchanged calcium. Finally, the purified and activated $\mathrm{BC}$ was dried at a $100{ }^{\circ} \mathrm{C}$ for $24 \mathrm{~h}$ in readiness for loading into the CA solution.

\section{Chemical analysis of BC}

The chemical components of the raw $\mathrm{BC}$, purified $\mathrm{BC}$ after reaction with $\mathrm{HCl}$, and activated $\mathrm{BC}$ after reaction with $\mathrm{Na}_{2} \mathrm{CO}_{3}$ were measured using atomic absorption spectroscopy (AAS; PYE Unicam SP191, Cambridge, UK). The AAS was calibrated, while solutions of the clay samples were prepared. In brief, $1 \mathrm{~g}$ of each clay sample was dissolved in $10 \mathrm{ml}$ of $\mathrm{H}_{2} \mathrm{SO}_{4}$ while stirring for $3 \mathrm{~h}$; then, the degree of absorption was calculated. Clay samples were then filtered, and small quantities of the filtrates were collected and diluted in a $250 \mathrm{ml}$ of water. Finally, AAS was used to determine each clay component using a $\mathrm{N}_{2} \mathrm{O}$-acetylene flame, and a hollow cathode lamp to calculate the proportion of each component $[72,73]$. 
Table 1 Electrospun nanofibres from different polymers with MMT fillers and their proposed applications

\begin{tabular}{|c|c|c|c|c|c|}
\hline $\begin{array}{l}\text { Polymer } \\
\text { system }\end{array}$ & Polymer name & $\begin{array}{l}\text { Single or hybrid clay fillers - with } \\
\text { or without modification }\end{array}$ & $\begin{array}{l}\text { Polymer solution- } \\
\text { nanofibre/clay } \\
\text { characterisations }\end{array}$ & $\begin{array}{l}\text { Suggested applications by } \\
\text { the reference authors }\end{array}$ & References \\
\hline \multirow[t]{22}{*}{$\begin{array}{l}\text { Single } \\
\text { polymer }\end{array}$} & Nylon 6 & MMT & $\begin{array}{l}\text { DSC, SEM, TEM, } \\
\text { WAXRD }\end{array}$ & - & [8] \\
\hline & Nylon 6 & O-MMT & $\begin{array}{l}\text { VIS, SEM, TEM, } \\
\text { WXRD, DSC, TGA, } \\
\text { MP }\end{array}$ & $\begin{array}{l}\text { High-performance filters } \\
\text { and fibre reinforcement } \\
\text { materials }\end{array}$ & [9] \\
\hline & Nylon 6 & O-MMT & $\begin{array}{l}\text { VIS, ST, SEM, AFM, } \\
\text { TEM, DWA }\end{array}$ & Water adsorption & {$[10]$} \\
\hline & Nylon 6 & $\begin{array}{l}(\mathrm{O}-\mathrm{MMT}) \text { with } \mathrm{Fe}_{2} \mathrm{O}_{3} \text { sputter } \\
\text { coating }\end{array}$ & $\begin{array}{l}\text { SEM-EDX, AFM, XPS, } \\
\text { TGA }\end{array}$ & Functional materials & {$[11]$} \\
\hline & Nylon 6 & $\mathrm{Fe}-\mathrm{OMT}$ & $\begin{array}{l}\text { TGA, HREM, SEM, } \\
\text { XRD, LR }\end{array}$ & - & {$[12]$} \\
\hline & Nylon 6 & Synthesised Fe-OMT & $\begin{array}{l}\text { FTIR, XRD, HREM, } \\
\text { SEM-EDX, TGA }\end{array}$ & - & {$[13]$} \\
\hline & Nylon 6 & MMT, O-MMT & $\begin{array}{l}\text { TGA, DSC, SEM, AFM, } \\
\text { XRD }\end{array}$ & - & {$[14]$} \\
\hline & Nylon 6 & $\begin{array}{l}\text { Synthesised Fe-OMT with } \\
\text { magnetron sputter coating }\end{array}$ & $\begin{array}{l}\text { HREM, SEM-EDX, } \\
\text { AFM, XPS, TGA, FP }\end{array}$ & Fire-protective fabrics & {$[15]$} \\
\hline & Nylon 6 & MMT clay & $\begin{array}{l}\text { SEM, TEM, EDX, XRD, } \\
\text { MP, BP, MA, LP, MG }\end{array}$ & $\begin{array}{l}\text { Coated packaging films } \\
\text { against oxygen and } \\
\text { moisture }\end{array}$ & {$[16]$} \\
\hline & Nylon 6 & MMT clay & TGA, SEM, TEM, CC & Fire-protective clothing & {$[17]$} \\
\hline & Nylon 6 & O-MMT & $\begin{array}{l}\text { VIS, EC, ST, WAXRD, } \\
\text { SEM, TEM }\end{array}$ & - & {$[18]$} \\
\hline & $\begin{array}{l}\text { Polyacrylonitrile } \\
\text { (PAN) }\end{array}$ & Na-MMT nanocomposites & XRD, TEM, SM & - & {$[19]$} \\
\hline & PAN & Synthesised Fe-OMT & $\begin{array}{l}\text { XRD, TEM, SEM, TGA, } \\
\text { FP, MP }\end{array}$ & Fire-protective fabrics & {$[20]$} \\
\hline & PAN & Sodium-activated (Na-MMT) & SEM, TEM, XRD, TGA & - & {$[21]$} \\
\hline & PAN & $\begin{array}{l}\text { Hexadecyl trimethyl ammonium } \\
\text { bromide (CTAB) modified MMT } \\
(\mathrm{MMT} / \mathrm{GO})\end{array}$ & $\begin{array}{l}\text { SEM, AFM, TEM, XRD, } \\
\text { TGA, MP }\end{array}$ & As nanofillers & {$[22]$} \\
\hline & PAN & Synthesised Na-MMT & $\begin{array}{l}\text { SEM, WAXRD, TGA, } \\
\text { IEP }\end{array}$ & Environmental protection & {$[23]$} \\
\hline & $\begin{array}{l}\text { Cellulose acetate } \\
\text { (CA) }\end{array}$ & MMT & $\begin{array}{l}\text { VIS, EC, TGA, DTG, } \\
\text { XRD, MP, SEM, EF- } \\
\text { TEM, EDX }\end{array}$ & - & {$[24]$} \\
\hline & $\mathrm{CA}$ & O-MMT & SEM, TEM, UV-S & Enzyme immobilisation & {$[25]$} \\
\hline & $\begin{array}{l}\text { Cellulose } \\
\text { extracted from } \\
\text { corn }\end{array}$ & Na-MMT & $\begin{array}{l}\text { XRD, FTIR, VIS, SEM, } \\
\text { DSC }\end{array}$ & - & {$[26]$} \\
\hline & $\mathrm{CA}$ & Anion surfactant/MMT & $\begin{array}{l}\text { SEM, FTIR, DSC, TGA, } \\
\text { XRD, HMA }\end{array}$ & $\begin{array}{l}\text { Heavy metal adsorbent in } \\
\text { water treatment }\end{array}$ & {$[27]$} \\
\hline & PVA & MMT & $\begin{array}{l}\text { FE-SEM, XRD, TGA, } \\
\text { MP }\end{array}$ & - & {$[28]$} \\
\hline & $\begin{array}{r}\text { MMW-PVA, } \\
\text { HMW-PVA }\end{array}$ & MMT & $\begin{array}{l}\text { VIS, FE-SEM, TEM, } \\
\text { TGA, MP }\end{array}$ & - & [29] \\
\hline
\end{tabular}


Table 1 continued

\begin{tabular}{|c|c|c|c|c|c|}
\hline $\begin{array}{l}\text { Polymer } \\
\text { system }\end{array}$ & Polymer name & $\begin{array}{l}\text { Single or hybrid clay } \\
\text { fillers - with or without } \\
\text { modification }\end{array}$ & $\begin{array}{l}\text { Polymer solution- } \\
\text { nanofibre/clay } \\
\text { characterisations }\end{array}$ & $\begin{array}{l}\text { Suggested applications by the } \\
\text { reference authors }\end{array}$ & References \\
\hline & PVA & MMT/Ag nanoparticles & $\begin{array}{l}\text { FE-SEM, TEM, XRD, } \\
\text { TGA, AP }\end{array}$ & Antibacterial applications & {$[30]$} \\
\hline & PVDF & Na-MMT & $\begin{array}{l}\text { WAXRD, FTIR, DSC, } \\
\text { TEM, SEM, VIS }\end{array}$ & - & {$[31]$} \\
\hline & PVDF & MMT & Crystallisation kinetics & - & [32] \\
\hline & PVDF & MMT & $\begin{array}{l}\text { FE-SEM, P, EU, DSC, } \\
\text { FTIR, IC }\end{array}$ & $\begin{array}{l}\text { Separators for lithium-ion } \\
\text { batteries }\end{array}$ & {$[33]$} \\
\hline & PU & O-MMT & $\begin{array}{l}\text { WAXRD, SEM, TEM, } \\
\text { EC, MP }\end{array}$ & - & {$[34]$} \\
\hline & PU & $\begin{array}{l}\text { Chlorhexidine acetate } \\
\text { drug }(\mathrm{CA}) / \mathrm{MMT}\end{array}$ & $\begin{array}{l}\text { SEM, XRD, CAM, P, } \\
\text { AP, DRM }\end{array}$ & $\begin{array}{l}\text { Topical drug delivery } \\
\text { application }\end{array}$ & {$[35]$} \\
\hline & PLA & Synthesised MMT & $\begin{array}{l}\text { SEC, DSC, TGA, TEM, } \\
\text { WAXRD, FTIR, PM }\end{array}$ & $\begin{array}{l}\text { Gas barrier for food } \\
\text { packaging applications }\end{array}$ & {$[36]$} \\
\hline & PLLA & MMT & SEM, XRD & $\begin{array}{l}\text { Engineered scaffold } \\
\text { applications }\end{array}$ & {$[37]$} \\
\hline & Silk fibron & MMT & $\begin{array}{l}\text { SEM, FE-SEM, TEM, } \\
\text { FTIR-XRD }\end{array}$ & $\begin{array}{l}\text { Scaffold for tissue } \\
\text { engineering }\end{array}$ & {$[38]$} \\
\hline & Levan & Na-MMT & $\begin{array}{l}\text { UV-S, SLS, DLS, } \\
\text { WAXRD, TGA, DSC, } \\
\text { FTIR, MP }\end{array}$ & $\begin{array}{l}\text { Cosmetics and } \\
\text { pharmaceutical coatings }\end{array}$ & [39] \\
\hline \multirow[t]{10}{*}{$\begin{array}{l}\text { Blends of } \\
\text { polymers }\end{array}$} & PLA/keratin & Na-MMT & $\begin{array}{l}\text { VIS, EC, SEM, TEM, } \\
\text { ATR-FTIR, DSC, } \\
\text { FPT }\end{array}$ & $\begin{array}{l}\text { Volatile organic compounds } \\
\text { (VOCs) removal filters from }\end{array}$ & {$[40]$} \\
\hline & Pullulan/PVA & MMT & $\begin{array}{l}\text { SEM, TEM, FTIR, } \\
\text { XRD, TGA, MP }\end{array}$ & - & [41] \\
\hline & Pullulan/PVA & MMT & $\begin{array}{l}\text { FE-SEM, TEM, XRD, } \\
\text { TGA, WAM, WRM, MP }\end{array}$ & Personal hygiene products & {$[42]$} \\
\hline & PVA/PVDF & O-MMT & $\begin{array}{l}\text { SEM, FTIR, TGA, MP, } \\
\text { IC, CV }\end{array}$ & Lithium-ion batteries & [43] \\
\hline & PVA/Chitosan & MMT & $\begin{array}{l}\text { FE-SEM, XRD, TEM, } \\
\text { MP, TGA }\end{array}$ & Reinforcement in matrix & {$[44]$} \\
\hline & PVA/PVP & $\begin{array}{l}\text { Octadecyl amine (ODA)- } \\
\text { MMT }\end{array}$ & $\begin{array}{l}\text { FTIR, XRD, FE-SEM, } \\
\text { TEM, EDX, TGA, } \\
\text { DSC, EC, TR }\end{array}$ & $\begin{array}{l}\text { Electrically conductive } \\
\text { nanomaterials }\end{array}$ & {$[45]$} \\
\hline & PVA/poly(VP-alt-MA) & $\begin{array}{l}\text { (ODA)-MMT + silver } \\
\text { (Ag) }\end{array}$ & & & \\
\hline & $\begin{array}{l}\text { PVA/Poly(MA-alt- } \\
\text { MVE) }\end{array}$ & (ODA)-MMT & $\begin{array}{l}\text { FTIR, XRD, FE-SEM, } \\
\text { EDX, CVMS }\end{array}$ & $\begin{array}{l}\text { Power, electrochemical and } \\
\text { fuel cell nanotechnology }\end{array}$ & {$[46]$} \\
\hline & $\begin{array}{l}\text { PVA/poly(maleic acid- } \\
\text { alt-acrylic acid) }\end{array}$ & (ODA)-MMT + Ag & $\begin{array}{l}\text { FTIR, XRD, SEM, } \\
\text { TGA, DSC, EC, TR, } \\
\text { CVMS }\end{array}$ & $\begin{array}{l}\text { Electrically conductive } \\
\text { nanomaterials }\end{array}$ & {$[47]$} \\
\hline & $\begin{array}{l}\text { PVA/poly(itaconic } \\
\text { anhydride-alt-2-vinyl, } \\
\text { 1,3 dioxalan) }\end{array}$ & (ODA)-MMT + Ag & $\begin{array}{l}\text { FTIR, XRD, FE-SEM, } \\
\text { TGA, DSC, EC, TR, } \\
\text { CVMS }\end{array}$ & $\begin{array}{l}\text { Microelectronics, } \\
\text { nanolithographical } \\
\text { technology and } \\
\text { semiconductors }\end{array}$ & [48] \\
\hline \multirow[t]{2}{*}{$\begin{array}{l}\text { Co- } \\
\text { polymers }\end{array}$} & Poly(MMA-CO-MAA) & Synthesised Na-MMT & $\begin{array}{l}\text { SEM, TEM, WAXRD, } \\
\text { TS, DLSM, PSR }\end{array}$ & - & {$[49]$} \\
\hline & PCL and G-PLA & (ODA)-Na-MMT + Ag & $\begin{array}{l}\text { FTIR, SEM-EDX, FE- } \\
\text { SEM, TEM, TGA }\end{array}$ & Biomedical applications & {$[50]$} \\
\hline
\end{tabular}


Table 1 continued

\begin{tabular}{lllll}
\hline $\begin{array}{l}\text { Polymer } \\
\text { system }\end{array}$ & Polymer name & $\begin{array}{l}\text { Single or hybrid clay fillers- } \\
\text { with or without modification }\end{array}$ & $\begin{array}{l}\text { Polymer solution- } \\
\text { nanofibre/clay } \\
\text { characterisations }\end{array}$ & $\begin{array}{l}\text { Suggested applications by } \\
\text { the reference authors }\end{array}$ \\
\hline & $\begin{array}{l}\text { Poly(vinyl alcohol-co- } \\
\text { vinyl acetate) }\end{array}$ & (ODA)-MMT $+\mathrm{Ag}$ & XRD, FE-SEM, AAT & $\begin{array}{l}\text { Food, bioengineering and } \\
\text { nano-engineering } \\
\text { processing }\end{array}$ \\
\hline
\end{tabular}

O-MMT organically modified montmorillonite, Fe-OMT organic-modified iron-montmorillonite, DWA dynamic water adsorption, XPS $\mathrm{X}$-ray photoelectron spectroscopy, FE-SEM field emission scanning electron microscope, HREM high-resolution electron microscopic, $L R$ laser Raman spectroscopic, XRD X-ray diffraction, WAXRD wide-angle X-ray diffraction, $M P$ mechanical properties, $F P$ flammability property, $E D X$ energy-dispersive X-ray, $B P$ barrier properties, $M A$ moisture absorption, $L P$ lipid peroxidation, $M G$ microbial growth, CC combustion characteristics, EC electrical conductivities, ST surface tension, DTG derivative thermogravimetric, FETEM field emission transition electron microscope, FTIR Fourier transform infrared spectroscopy, ATR-FTIR attenuated total reflectance-Fourier transform infrared spectroscopy, DSC differential scanning calorimetry, UV-S ultraviolet visible spectrophotometry, $S M$ storage modulus, IEP ion exchange properties, $A P$ antimicrobial performance, $P$ porosity, $E U$ electrolyte uptake, $C A M$ contact angle measurement, DRM drug release measurements, SEC size exclusion chromatography, PM permeability measurements, $S L S$ static light scattering, DLS dynamic light scattering, WAM water absorbency measurement, WRM water retention measurement, FPT filtration performance tests, IC ionic conductivity, $C V$ cyclic voltammetry, TR thermal resistance, CVMS current-voltage measurement system, TS thermal stability, DLSM dynamic light scattering measurement, PSR polymer solution rheology, AAT antifungal and antimicrobial testing, $T G A$ thermogravimetric analysis, $H M A$ heavy metal absorption

\section{Fabrication of $\mathrm{CA} / \mathrm{BC}$ composite nanofibrous fabrics}

A predetermined amount of BC with 4 wt $\%$ CMC was mixed and added to hot aqueous $\mathrm{AcOH}$ (75:25, $\mathrm{v} / \mathrm{v}$ ) while stirring magnetically at $300 \mathrm{r} \mathrm{min}^{-1}$ at room temperature for up to $2 \mathrm{~h}$. In parallel, CA was dissolved in aqueous $\mathrm{AcOH}(75: 25, \mathrm{v} / \mathrm{v})$ at concentrations of $15 \%(\mathrm{w} / \mathrm{v})$ while stirring with $300 \mathrm{r} \mathrm{min}^{-1}$ at $70{ }^{\circ} \mathrm{C}$ for to $5 \mathrm{~h}$. The CA/BC solutions were blended with a $5,10,15,20,25 \mathrm{wt} \%$ of $\mathrm{BC}$ (with respect to the weight of $C A$ ) and $C A$ solution while stirring magnetically at $300 \mathrm{r} \mathrm{min}^{-1}$ at room temperature for up to $24 \mathrm{~h}$. Samples nomenclature is coded in this work in the form of 'CA15BCX' which refers to a CA solution at $15 \%(\mathrm{w} / \mathrm{v})$ concentration, where ' $\mathrm{X}$ ' indicates the concentration of $\mathrm{BC} w \mathrm{t} \%$. The CA/BC composite nanofibres from each spinning solution are referred to as CA15BC0, CA15BC5, CA15BC10, CA15BC15, CA15BC20 and CA15BC25, respectively. Nanofibrous fabrics from the $\mathrm{CA} / \mathrm{BC}$ blends were electrospun using a NS LAB 200 Nanospider electrospinner (Elmarco, Czech Republic) using the fourwire electrode. The applied voltage and working distance were $65-75 \mathrm{kV}$ and $12 \mathrm{~cm}$, respectively. The rotation speed of the electrode was 1-2 $\mathrm{r} \mathrm{min}^{-1}$, and the linear speed of the collector was $10 \mathrm{~cm} \mathrm{~min}^{-1}$.
Fibres were deposited on to a spunbond polypropylene (PP) nonwoven fabric containing fibres of $3 \pm 0.30$ denier. The environmental temperature was $23 \pm 2{ }^{\circ} \mathrm{C}$, and the relative humidity was $30 \%$. The as-spun fibre webs were dried for at least 3 days at room temperature.

\section{Viscosity, surface tension and electrical conductivity measurements}

The viscosities of $\mathrm{CA} / \mathrm{BC}$ solutions were measured on a Brookfield digital viscometer (Brookfield DV-II Viscometer, USA). Readings were taken at $23 \pm 2{ }^{\circ} \mathrm{C}$ using a spindle and chamber SC4-25/13R. CA/BC solutions volume of $16.1 \mathrm{~mL}$ for each sample was placed in a beaker, into which the spindle of the viscometer was immersed and rotated at a shear rate in the range from 60 to $1 \mathrm{rpm}$ (equivalent to $1-0.017 \mathrm{~s}^{-1}$ in order to characterise the rheological properties of the $\mathrm{CA} / \mathrm{BC}$ solutions.

The surface tension of the $\mathrm{CA} / \mathrm{BC}$ solutions was analysed by means of the pendant drop method using a CAM 200 contact angle goniometer (KSV Instruments Ltd., Helsinki, Finland). A pendant drop method in six parallel measurements using a microsyringe with an automatic dispenser and a CCD fire wire camera $(512 \times 480)$ with telecentric zoom optics 
combined with LED-based background lighting allowing capturing images at frame intervals from $10 \mathrm{~ms}$ to $1000 \mathrm{~s}$ was carefully conducted. Each sample was analysed in triplicate, and the mean values of the triplicates were plotted. The surface tension $\gamma$ was calculated by using the equation:

$\gamma=\frac{g \cdot \rho \cdot d_{e}^{2}}{S_{f}}$

where $g$ is the acceleration of gravity, $\rho$ is the difference in density of the air and the solution, de is the equatorial diameter of the droplet and $S_{f}$ is the shape factor, as referenced in [74].

Electrical conductivity of CA/BC solutions was examined by Novocontrol broadband dielectric impedance spectrometer (Germany), with integrated alpha-A high-performance frequency analyser in $0.1 \mathrm{~Hz}$ to $10 \mathrm{MHz}$ frequency. Samples were tightened by using vacuum-sealed parallel electrodes (diameter of $18 \mathrm{~mm}$ ) as a specimen holder cell with a spring for sealing out the air, and the data were analysed by using WinFit software. Measurements were taken at a temperature of $23 \pm 2{ }^{\circ} \mathrm{C}$, and the spectrometer was set to a bias of $1 \mathrm{~V}$ and was measured between frequency sweeps of $1.0 \mathrm{~Hz}$ to $1.8 \mathrm{MHz}$.

\section{Scanning electron microscopy (SEM)} and energy-dispersive X-ray spectroscopy (EDX)

The 2D surface morphology of the $\mathrm{BC}$ and the fabric structure of the CA/BC nanofibres were observed by SEM (Hitachi S-2600 N, Japan) with a secondary electron detector. Samples were sputter-coated with high-resolution sputter coater (Emitech K550X, UK) with gold layers under high vacuum. An acceleration voltage of $3-5 \mathrm{kV}$ was used with a working distance of 5.3-11.0 mm. Images were captured at magnifications in the range of $70 \times$ to $30000 \times$. The average fibre diameters in each sample were estimated by evaluating a minimum of 50 fibres from different regions of the sample. The average electrospun CA nanofibre diameters were measured from multiple SEM images by means of image analysis software (SemAfore 5.21, JEOL CO., Finland) with at least 50 measurements per image to determine mean fibre diameter and associated frequency distributions. Values were expressed as mean \pm standard error. In order to analyse the elemental components presented in the clay such as silicon and iron, EDX spectrum with
Oxford instruments Aztec energy EDS analysis software and 80-mm X-Max SDD detector were applied.

\section{Transmission electron microscopy (TEM) and nanoscale EDX mapping}

TEM (FEI Titan3 Themis 300, FEI $^{\mathrm{TM}}$ Netherland) and nanoscale EDX elemental quantitative mapping (FEI Super-X 4-detector EDX system) were used to confirm coexistence and to determine the size distribution and structure of the $\mathrm{BC}$ within the nanofibres. $\mathrm{CA} / \mathrm{BC}$ nanofibres were collected onto carbon-coated grids with a 300 mesh. Images were taken at an acceleration voltage of $300 \mathrm{kV}$.

\section{Structure and thermal analysis of CA/BC composite nanofibrous fabrics}

A wide-angle X-ray diffraction (WAXD, Bruker AXS D8 advanced, Germany) analyses were carried out in order to study the structural properties of $\mathrm{BC}$ and CA/BC composite nanofibres. Samples were scanned under conditions as the following scanning angle between $2 \theta=2^{\circ}$ and $60^{\circ}$ under room temperature, wave length of the X-ray beam of $0.154018 \mathrm{~nm}(\mathrm{Cu} \mathrm{Ka}$ anode and cathode radiation), a scan speed of $1^{\circ} \mathrm{min}^{-1}$, working voltage of $40 \mathrm{kV}$ and working current of $40 \mathrm{~mA}$.

Thermal analyses of BC and CA15BC0, CA15BC5 and $\mathrm{CA} 15 \mathrm{BC} 10$ electrospun composite nanofibres which include mass loss wt $\%$ and heat flow $\left(\mathrm{W} \mathrm{g}^{-1}\right)$ as a function of heating temperature were conducted by using thermogravimetric analyser and differential scanning calorimeter (TGA/DSC 1 Star system, Mettler Toledo, Switzerland). A heating temperature of $40-600{ }^{\circ} \mathrm{C}$ and a heating rate of $10^{\circ} \mathrm{C} \mathrm{min}^{-1}$ in nitrogen with flow rate of $50 \mathrm{~cm}^{3} \mathrm{~min}^{-1}$ were applied. Specimen weights of 2-10 mg were applied.

\section{Results and discussion}

\section{Purification, activation and suspension of BC}

The BC mineral composition mainly comprises smectite groups such as montmorillonite, beidellite, saponite and hectorite with impurities such as dolomite and illite [75]. Table 2 gives the measured chemical compositions of the raw, purified and 
Table 2 Chemical composition (wt $\%$ ) of raw, $\mathrm{HCl}$-purified and $\mathrm{Na}_{2} \mathrm{CO}_{3}$ activated $\mathrm{BC}$

\begin{tabular}{lllllllllll}
\hline Materials & $\mathrm{SiO}_{2}$ & $\mathrm{Al}_{2} \mathrm{O}_{3}$ & $\mathrm{Fe}_{2} \mathrm{O}_{3}$ & $\mathrm{MgO}$ & $\mathrm{CaO}$ & $\mathrm{CO}_{2}$ & $\mathrm{H}_{2} \mathrm{O}$ & $\mathrm{Na}_{2} \mathrm{O}$ & $\mathrm{TiO}_{2}$ & Sum \\
\hline Raw BC & 46.6 & 14.4 & 7.2 & 6.7 & 5.8 & 6.2 & 12.8 & 0.13 & 0.16 & 99.99 \\
HCl-purified BC & 53.5 & 16.5 & 7.9 & 4.5 & 2.2 & - & 14.8 & 0.08 & 0.13 & 99.61 \\
$\mathrm{Na}_{2} \mathrm{CO}_{3}$-activated BC & 51.8 & 16.6 & 7.8 & 4.3 & 2.16 & 1.37 & 13.6 & 2.1 & 0.13 & 99.86 \\
\hline
\end{tabular}

activated $\mathrm{BC}$, which includes metal oxides such as $\mathrm{SiO}_{2}, \mathrm{Al}_{2} \mathrm{O}_{3}, \mathrm{Fe}_{2} \mathrm{O}_{3}, \mathrm{MgO}, \mathrm{CaO}, \mathrm{Na}_{2} \mathrm{O}, \mathrm{TiO}_{2}$, water and carbon dioxide $\left(\mathrm{CO}_{2}\right)$. The origin of $\mathrm{CO}_{2}$ in the raw clay is due to dissociation of calcium carbonate or magnesium carbonate [76]. Purification can be achieved with $\mathrm{HCl}$ [77]. It is apparent from the compositions of purified $\mathrm{BC}$ treated with $\mathrm{HCl}$ that $\mathrm{CO}_{2}$ is effectively removed. In addition, $\mathrm{HCl}$-purified $\mathrm{BC}$ has greater $\mathrm{SiO}_{2}, \mathrm{Al}_{2} \mathrm{O}_{3}$ and $\mathrm{Fe}_{2} \mathrm{O}_{3}$ content than untreated BC.

Calcium BC was completely converted to sodium $\mathrm{BC}$ when the clay was activated by $\mathrm{Na}_{2} \mathrm{CO}_{3}$ at $(2.5-5 \%)$ ratio $[78,79]$. Hence, $\mathrm{Na}^{+1}$ smectite clay is one of the preferred layered materials for the preparation of nanocomposites because of its high cation exchange capacity, high surface area, strong adsorption/absorption capacities within their interlamillar spaces and thus swelling capacity [80]. It is clear from the compositions of activated $\mathrm{BC}$ with $\mathrm{Na}_{2} \mathrm{CO}_{3}$ that $\mathrm{Ca}^{+}$ions were exchanged by $\mathrm{Na}^{+}$ions where $\mathrm{Na}_{2} \mathrm{O}$ became $2.1 \%$ after it was $0.13 \%$ when 4 wt $\%$ of $\mathrm{Na}_{2}$ $\mathrm{CO}_{3}$ was added. However, in addition to the purification and activation achieved, the $\mathrm{HCl}$ and $\mathrm{Na}_{2} \mathrm{CO}_{3}$ treatments partially altered the morphological structure of the clay which will be clarified hereinafter.

We believe that the main challenge for processing composite nanofibres at the present time is to improve the dispersion and suspension of the $\mathrm{BC}$ particles in the polymer solution for enhancing the morphological uniformity of the electrospun nanofibres. It has been reported that activation of bentonite clay with $\mathrm{Na}_{2} \mathrm{CO}_{3}$ [increasing the $\left(\mathrm{Na}^{+} / \mathrm{Ca}^{+2}\right.$ ratio)] will improve the thixotropic behaviour of bentonite particles suspensions and dispersions [78]. It has been also found that $\mathrm{CMC}$ has the ability to suspend the clay particles in the polymer solution and delay their precipitation at the bottom of the electrospinning bath. This is due to the carboxyl group in the CMC which causes water dispersibility and an increase in the apparent and plastic viscosity [81]. Based on the advantages of $\mathrm{CMC}$ and $\mathrm{Na}_{2} \mathrm{CO}_{3}$, we have purified, activated and mixed the low cost bentonite clay with $\mathrm{CMC}$ and $\mathrm{Na}_{2} \mathrm{CO}_{3}$ rather than buying sodium montmorillonite clay. In order to obtain a stable and uniform suspension of BC in the CA solution, $4 \mathrm{wt} \%$ of $\mathrm{CMC}$ was added to the hot wet activated $\mathrm{BC}$. By mixing $\mathrm{Na}_{2} \mathrm{CO}_{3}$ before adding the $\mathrm{CMC}$, it is possible to promote an efficient reaction because the CMC hydrogel can obstruct the reaction in which the $\mathrm{Ca}^{+}$ions are exchanged by $\mathrm{Na}^{+}$ions [79]. Figure 1 summarises the stages forms of the BC obtained through processing, from the original mined state.

\section{Electrospinning of $\mathrm{CA} / \mathrm{BC}$ composite nanofibrous fabrics}

Figure 2 shows the electrospinning set-up using the wire electrode. As the electrode rotates through the polymer solution, a thin film of charged liquid is formed on the wire. As the wires emerge from the polymer solution, the film on the wire undergoes Plateau-Rayleigh instability resulting in multiple droplet formation along the length [69]. If the electric field is sufficiently high, jets of polymer solution form from the droplets to produce filaments that can be collected above, as shown in Fig. 2.

Using wires or cylindrical electrodes, we have found that fibre formation is similar for both, but there are differences in the droplet formation mechanism, shape and size. With the wire electrode, droplet formation depends on viscosity, surface tension and electrical conductivity of the polymer solution, the rotational speed and the applied electric field. Based on experience of the both systems, we suggest that it is desirable to operate the cylindrical electrode system with a low polymer solution concentration and a lower viscosity than for the wire electrode. In the present experiments using the wire electrode, a spinning solution of $15 \mathrm{wt} \%$ CA with (0-25 wt\%) BC loading was found to yield the highest productivity and electrospinning stability. The optimal voltage range was $65-75 \mathrm{kV}$ using a $12 \mathrm{~cm}$ spinning distance. As the $\mathrm{BC}$ loading increased, so too did the viscosity and surface tension, requiring a higher voltage and 

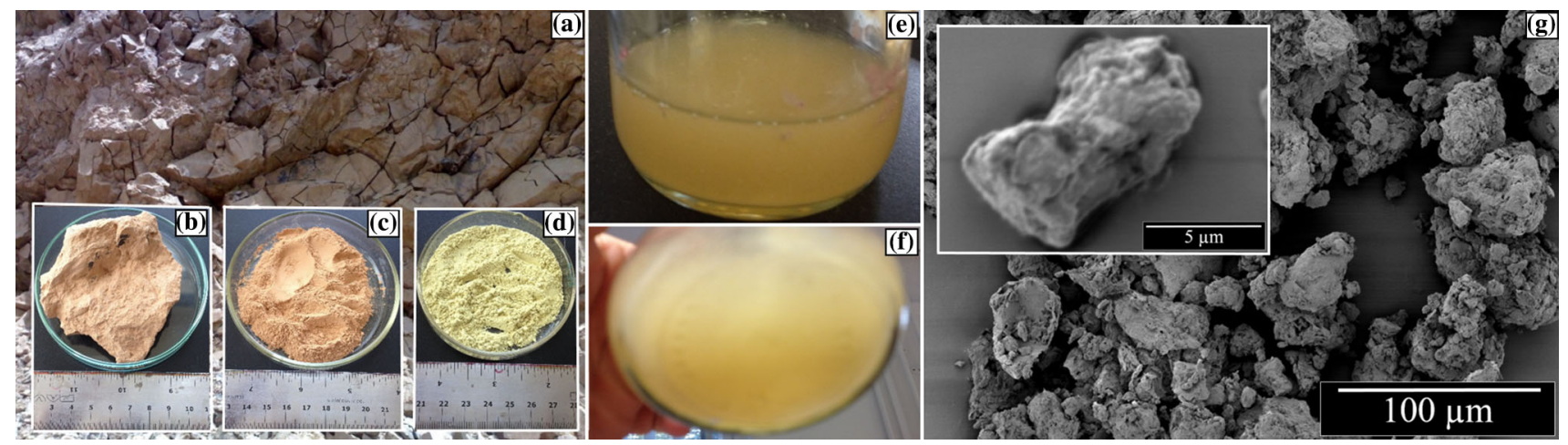

Figure 1 a Naturally occurring BC, $\mathbf{b}$ crushed BC, $\mathbf{c}$ ground BC, $\mathbf{d}$ sieved, purified and activated BC, $\mathbf{e}, \mathbf{f}$ uniform solution of CA loaded with purified, activated and dispersed $\mathrm{BC}$ and $\mathrm{g}$ SEM images of raw untreated $\mathrm{BC}$ microstones.

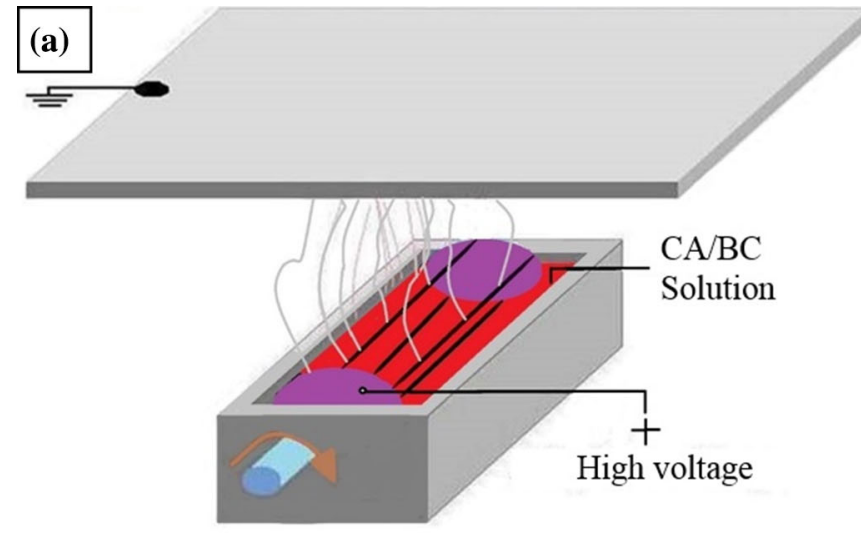

Figure 2 a Schematic of the free surface electrospinning set-up based on a four-wire spindle electrode, $\mathbf{b}$ real image of the free surface electrospinning set-up using a four-wire spindle electrode

lower wire rotation speed to maintain stable spinning conditions.

\section{Morphology of $\mathrm{HCl}$-purified and $\mathrm{Na}_{2} \mathrm{CO}_{3}-$ activated $\mathrm{BC}$ and $\mathrm{CA} / \mathrm{BC}$ composite nanofibres}

SEM images of $\mathrm{HCl}$-purified and $\mathrm{Na}_{2} \mathrm{CO}_{3}$-activated $\mathrm{BC}$ are shown in Fig. 3, and pronounced differences were noted in the respective architectures. The HClpurified BC particle sizes in Fig. 3a ranged from c. 5-60 $\mu \mathrm{m}$ with evidence of aggregation, and porosity in the exposed BC surfaces. In Fig. $3 b$, the $\mathrm{Na}_{2} \mathrm{CO}_{3}$ activated and $\mathrm{HCl}$-purified $\mathrm{BC}$ is reacted with $\mathrm{CMC}$ and $(\mathrm{AcOH} /$ water $)(75 / 25, \mathrm{v} / \mathrm{v})$ as a mimicry to the $\mathrm{BC}$ state during electrospinning. There was a decrease in the size of $\mathrm{BC}$ particles and an increase in the apparent porosity of the $\mathrm{BC}$ surface compared to

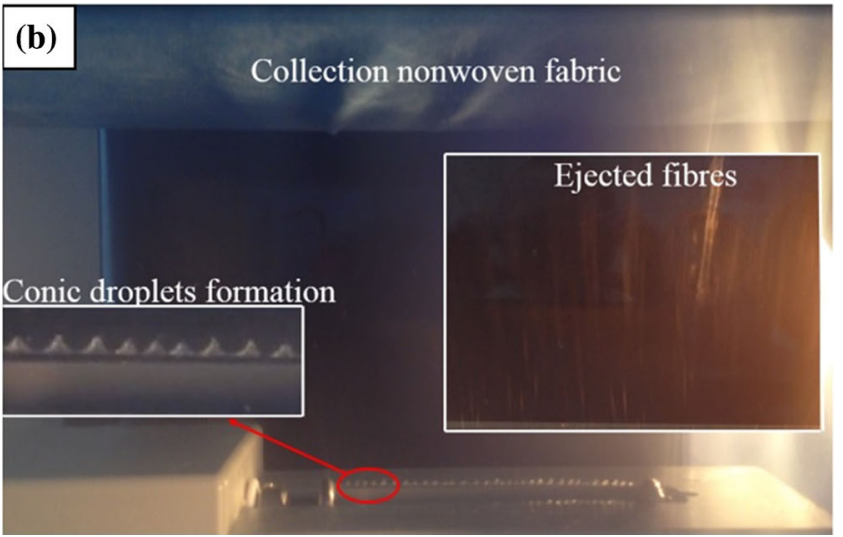

and a nonwoven PP fabric collector. Inset is a magnified image of conical droplet formation.

the HCl-purified BC. Note also that in Fig. 3b, the shape of the BC can be characterised as a flake-like sheet arranged in a layered formation. This is an indication of particle distortion, fragmentation and exfoliation by the action of $\mathrm{AcOH}$, water, $\mathrm{CMC}$ and $\mathrm{Na}_{2} \mathrm{CO}_{3}$. In fact, the observations obtained herein are in reasonable agreement with those in the literature for BC [82]. Figure 3c shows a SEM image of electrospun purified and activated $\mathrm{BC}$ fibres produced from an $(\mathrm{AcOH} /$ water) solution. Electrospun $\mathrm{BC}$ particles attached to the PP spunbond nonwoven fabric were fragmented into particles as small as $100 \mathrm{~nm}$ of various shapes. Amrani et al. stated the cause of the separation of layers due to the phenomenon of hydrophobia with the migration of hydronium ions towards the surface and the transformation of their crystal lattice [77]. However, we believe that the applied electric field plays a part in 

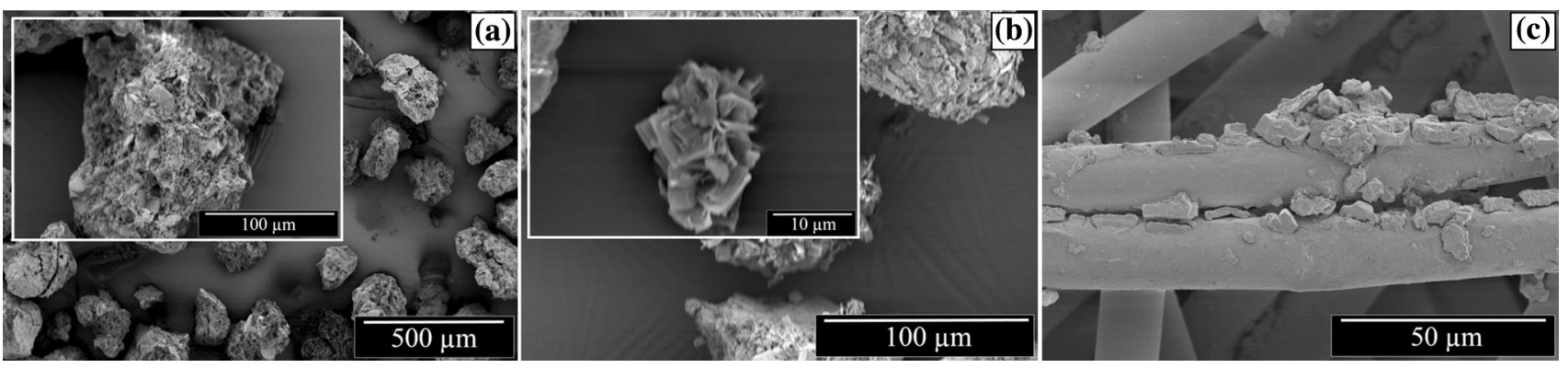

Figure 3 SEM images of a $\mathrm{HCl}$-purified $\mathrm{BC}$, $\mathbf{b ~ N a} \mathrm{NO}_{3}$-activated, $\mathrm{HCl}$-purified $\mathrm{BC}$ and reacted with $\mathrm{CMC}$ and $(\mathrm{AcOH} /$ water) and c electrospun purified and activated $\mathrm{BC}$ from $(\mathrm{AcOH} /$ water) solution.
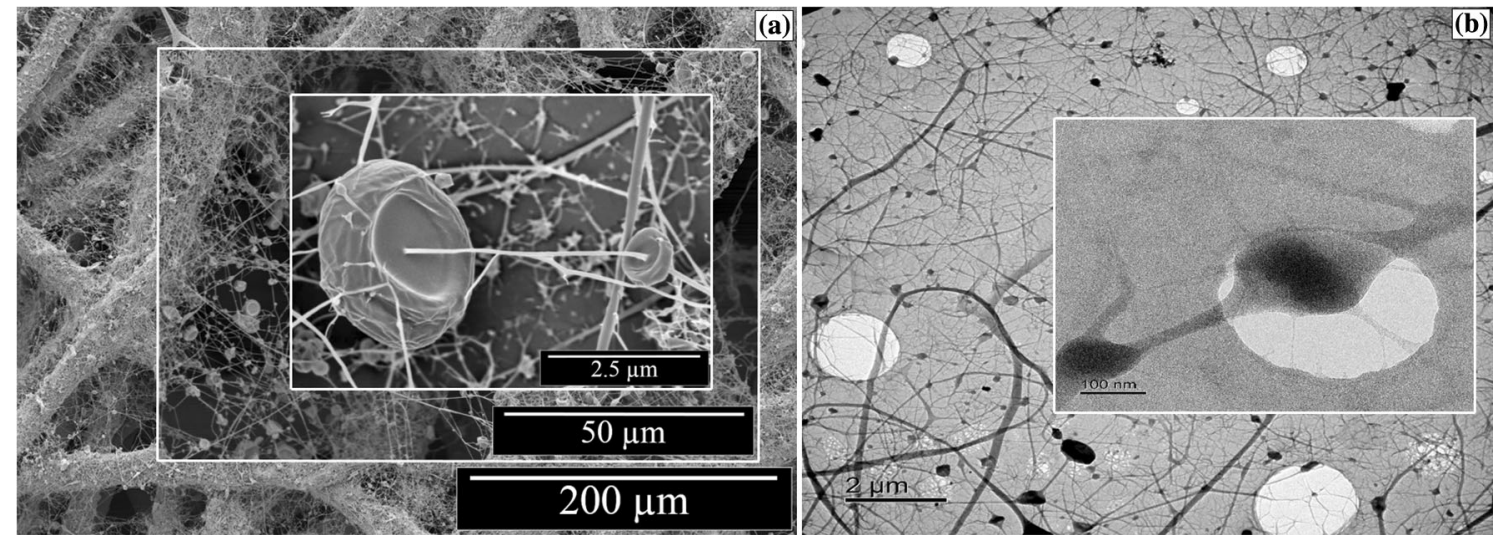

Figure 4 SEM (a) and TEM (b) images of CA nanofibres fabricated from a $15 \mathrm{wt} \% \mathrm{CA}$ solution with $10 \mathrm{wt} \% \mathrm{BC} / \mathrm{CA}$ loading.

the fragmenting and disintegrating the $\mathrm{BC}$ during electrospinning, which is reflected by substantial difference in the clay sizes before and after electrospinning.

Typical SEM and TEM images of the CA nanofibres fabricated from a $15 \mathrm{wt} \%$ CA solution in $(\mathrm{AcOH}$ : water) with $10 \mathrm{wt} \% \mathrm{BC} / \mathrm{CA}$ loading are shown in Fig. $4 a, b$. All of the nanofibres were randomly distributed to form a porous web of nanofibres penetrating semi-spherical features resembling jellyfish. The TEM image confirms that the different sizes and shapes of BC were incorporated within these jellyfish-like features.

Figure 5a-i presents SEM images of electrospun CA nanofibres in Fig. 5a; CA/BC composite nanofibres with different BC loadings in Fig. $5 b-f$, g; fibre diameter distributions of image $(\mathrm{a})$; and $(\mathrm{h}, \mathrm{i})$ diameter distributions of jellyfish features of image $(b)$ and image (c), respectively. Fabric of CA nanofibres loaded with BC was readily electrospun forming fibres ranging from 30 to $280 \mathrm{~nm}$ with mean fibre diameters of 70-100 and positively skewed diameter distributions and the jellyfish features ranging from $100 \mathrm{~nm}$ to $2.5 \mu \mathrm{m}$ in diameter with mean diameter of $0.5-0.7 \mu \mathrm{m}$ and positively skewed diameter distributions. It is evident that, at higher BC loading, the formation of continuous composite nanofibres was difficult due to the inability to preserve stable flow of the polymer solution loaded with clay from the droplets on the wire electrode. Briefly, electrospun nanofibres loaded with activated BC with a smaller diameter and thus a higher surface area could be produced uniformly when the BC loading was reduced to $5-10 \mathrm{wt} \%$, but nonuniform fibres and beads were formed if the loading was increased to 15-25 wt $\%$. Nevertheless, the electrospun nanofibre diameters resulting from $15 \mathrm{wt} \%$ CA solutions were nearly the same at all $\mathrm{BC} / \mathrm{CA}$ loading levels as shown in Fig. 5.

The interior morphologies of CA/BC nanofibres for all samples were studied using TEM as shown in Fig. 6a-f. Figure 6a shows dark spots which correspond to the BC lamella inside the jellyfish features. The encapsulated BC within these features was of 

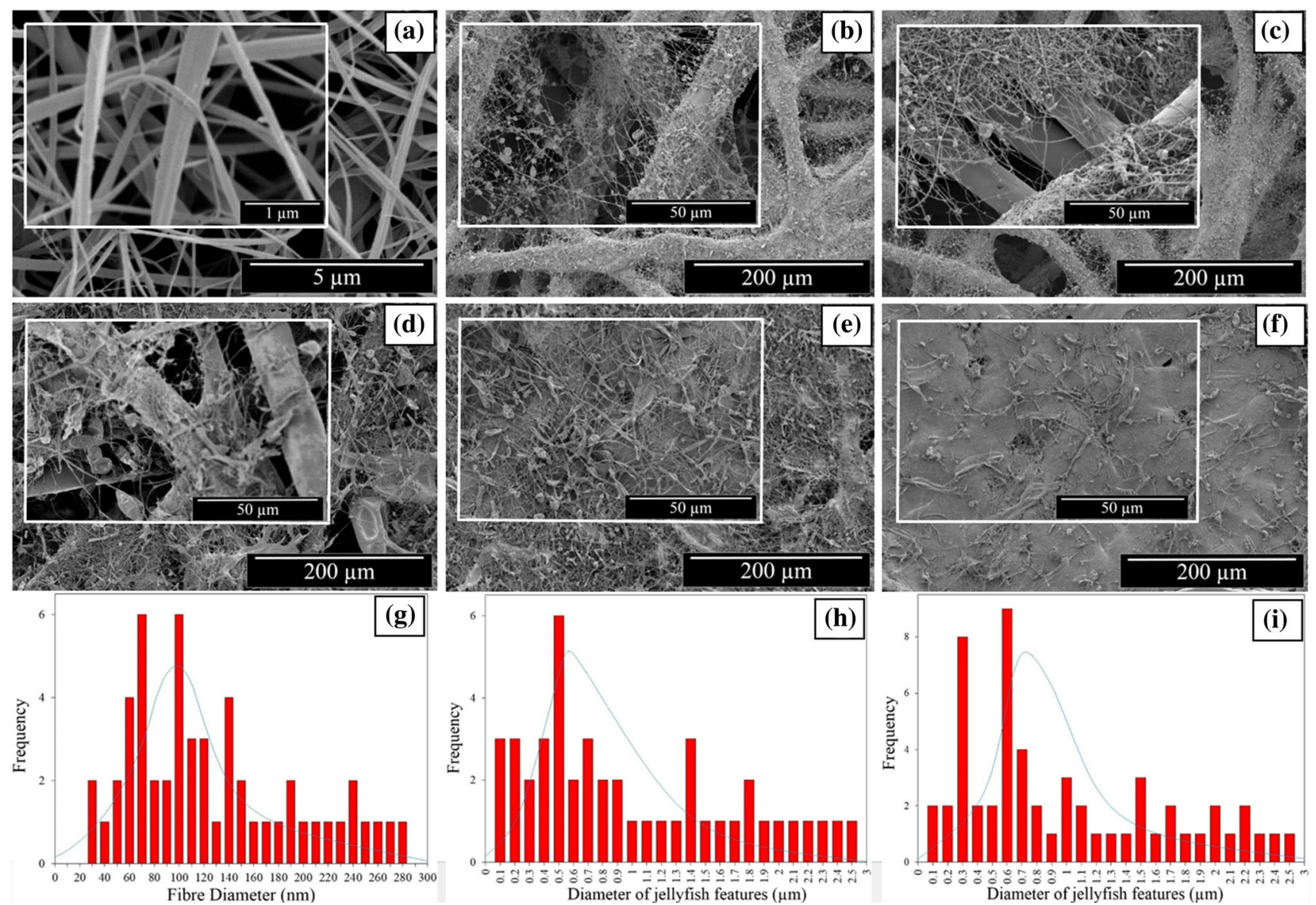

Figure 5 SEM images of $\mathrm{CA}$ and $\mathrm{CA} / \mathrm{BC}$ nanofibres. a SEM image of electrospun $\mathrm{CA}$ nanofibre at $15 \mathrm{wt} \% \mathrm{CA}$ solution. SEM images of $\mathrm{CA} 15 \mathrm{BC} 5$ (b), CA15BC10 (c), CA15BC15 (d),

different sizes and shapes and was well distributed within the $\mathrm{CA}$ fabric when the $\mathrm{BC}$ loading was low (see Fig. 6 b, c). The BC preferentially resided within the interior and at the interfacial regions. By contrast, as shown in Fig. $6 \mathrm{~d}-\mathrm{f}$ poor dispersion and interfacial contact of the BC occurred when the loading concentration increased to more than $15 \mathrm{wt} \%$. This is to be expected for two reasons. Firstly, the stress resulting from agglomeration of $\mathrm{BC}$ at high loadings and, secondly, the high loading of $\mathrm{BC}$ is likely to increase the surface tension and viscosity of the polymer solution, leading to instability during the electrospinning process. As a result, we have found that the maximum $\mathrm{BC}$ loading to obtain optimal dispersion and distribution of $\mathrm{BC}$ within the $\mathrm{CA}$ nanofibrous structure is $10 \mathrm{wt} \%$, while, if the loading increases to 15,20 or $25 \mathrm{wt} \%$, bead formation is prevalent.
CA15BC20 (e) and CA15BC25 (f). g: Fibre diameter distributions of ( $\mathbf{g}$ ) image $\mathbf{a}$ and $\mathbf{h}, \mathbf{i}$ diameter distributions of jellyfish features of (h) image $\mathbf{b}$ and $\mathbf{i}$ image $\mathbf{c}$.

The elemental analysis of $\mathrm{HCl}$-purified BC compositions was confirmed by the EDX analysis in Fig. 7a. Note that the HCl-purified BC consisted mainly of $\mathrm{O}, \mathrm{Si}, \mathrm{Fe}, \mathrm{Al}$ and $\mathrm{Mg}$ as inorganic bases for the metal oxides $\mathrm{SiO}_{2}, \mathrm{Al}_{2} \mathrm{O}_{3}, \mathrm{Fe}_{2} \mathrm{O}_{3}$ and $\mathrm{MgO}$, which are instrumental in providing material functionality [2]. Figure $7 \mathrm{~b}$ reflects the TEM and EDX data for CA15BC5 and the embedding of $\mathrm{BC}$ within the CA nanofibres. The EDX spectra recorded at specific points revealed $\mathrm{C}, \mathrm{O}, \mathrm{Na}, \mathrm{Mg}, \mathrm{Al}, \mathrm{Si}, \mathrm{Ca}$ and $\mathrm{Fe}$ in the $\mathrm{CA}$, semi-spherical jellyfish-like features, penetrated by $\mathrm{CA}$ nanofibre. Note also that the existence of $\mathrm{C}$ and $\mathrm{Na}$ is indicative of $\mathrm{CA}$ with a $\mathrm{Na}_{2} \mathrm{CO}_{3}$-activated component.

A nanoscale TEM-EDX elemental quantitative mapping in Fig. 8 detected $\mathrm{C}$ as a primary component of the $\mathrm{CA} / \mathrm{BC}$ composite nanofibrous fabric, and the $\mathrm{BC}$ layers consisted of $\mathrm{O}, \mathrm{Al}, \mathrm{Si}, \mathrm{Fe}, \mathrm{Na}, \mathrm{Mg}$ and 

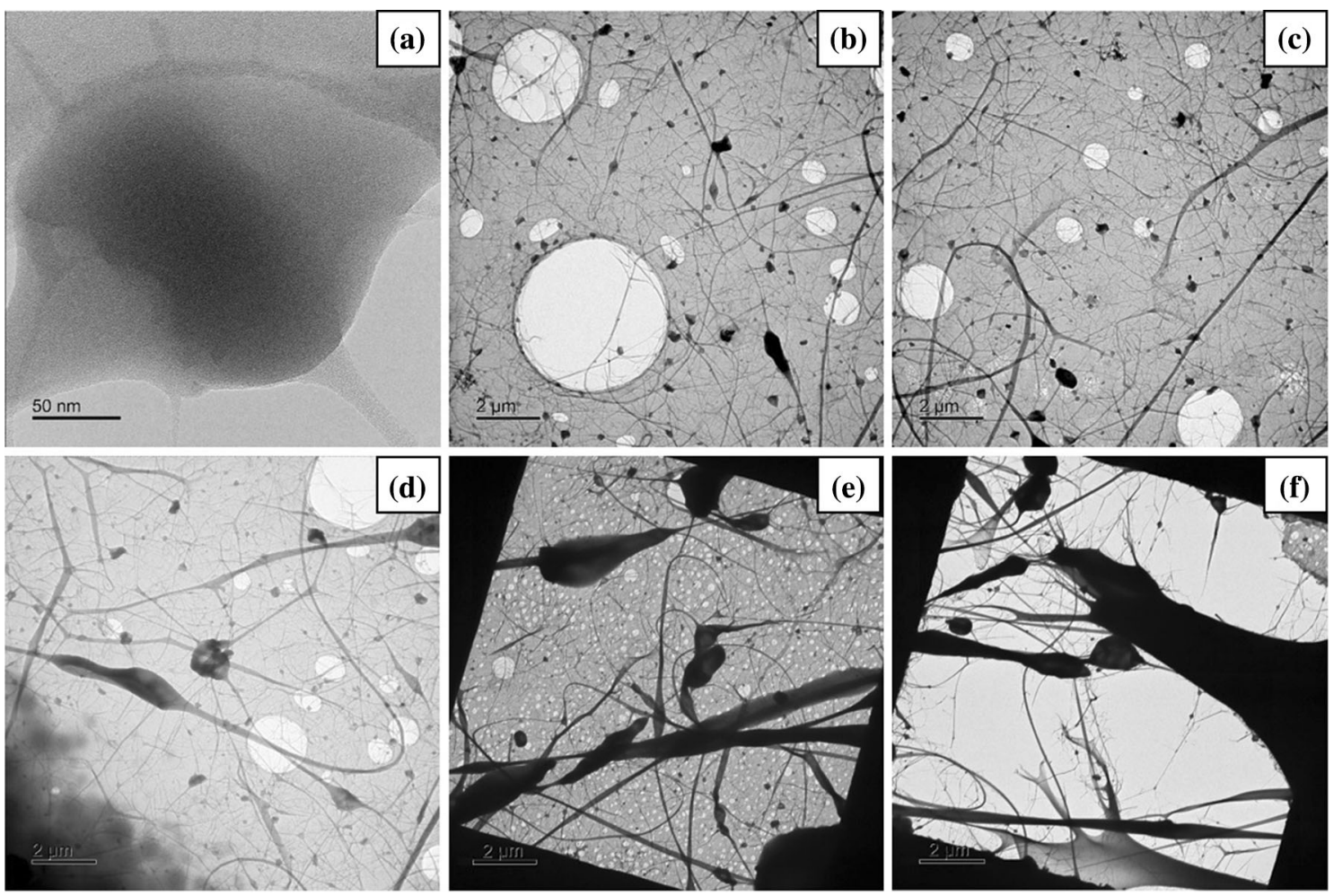

Figure 6 TEM images of electrospun $\mathrm{CA} / \mathrm{BC}$ composite nanofibres. a TEM image of CA15BC10 at $50 \mathrm{~nm}$ bar. TEM images of CA15BC5 (b), CA15BC10 (c), CA15BC15 (d), CA15BC20 (e) and CA15BC25 (f).

Ca distributed in varying proportions throughout the CA nanofibrous fabric.

\section{Viscosity, surface tension and electrical conductivity of $\mathrm{CA} / \mathrm{BC}$ solutions}

Free surface electrospinning can only be accomplished when process parameters are conveniently controlled, such as evaporation rate of the solvent, as well as viscosity, surface tension and electrical conductivity of the electrospinning polymer solution. Convenient evaporation rates for $\mathrm{CA} / \mathrm{BC}$ spinning are critical to ensure stable fibre production, since solvents having high evaporation rates such as acetone, chloroform and methanol tend to obstruct jet formation from droplets on the electrode wires [83]. On the other hand, very low evaporation rates lead to film rather than fibre formation. By selecting a binary solvent system of $\mathrm{AcOH}$ and water (75:25) with boiling point of 118 and $100{ }^{\circ} \mathrm{C}$, respectively, stable spinning conditions were achieved [84] and it is well established that when the ratio of $\mathrm{AcOH}$ to water is $75: 25$, nanofibrous cellulose fibres can be successfully generated without formation of beads [24].

The shear viscosities of dissolved $\mathrm{CA}$ at concentration of $15 \%(\mathrm{w} / \mathrm{v})$ and $\mathrm{CA} / \mathrm{BC}$ at various loading rates of $\mathrm{BC}$ are plotted in Fig. 9a. The shear viscosities of the CA/BC increased with increasing BC concentration which is to be expected. A higher shear viscosity was observed for CA15BC25 due mainly to the incorporation of a high clay loading rather than the molecular weight of the CA. In Fig. 9a, the CA/BC shear viscosity values at a $0.017 \mathrm{~s}^{-1}$ shear rate mimic the prevailing conditions due to the revolution of the wire electrode at $1 \mathrm{r} \mathrm{min}^{-1}$. Indeed, these viscosity values necessitated the use of voltages of at least $65 \mathrm{kV}$ for CA15BC0 and $75 \mathrm{kV}$ for CA15BC25 to induce electrical forces high enough to overcome the viscoelastic forces needed to form jets from droplets on the electrode wires [65].

The surface tension of dissolved $\mathrm{CA}$ at a concentration of $15 \%(\mathrm{w} / \mathrm{v})$ and $\mathrm{CA} / \mathrm{BC}$ at various $\mathrm{BC}$ loadings is given in Fig. 9b. The surface tension values of the CA/BC decreased with a decrease in BC concentration. For example, the surface tension decreased from $41.62 \pm 1.2 \mathrm{mN} / \mathrm{m}$ for CA15/BC25 to 

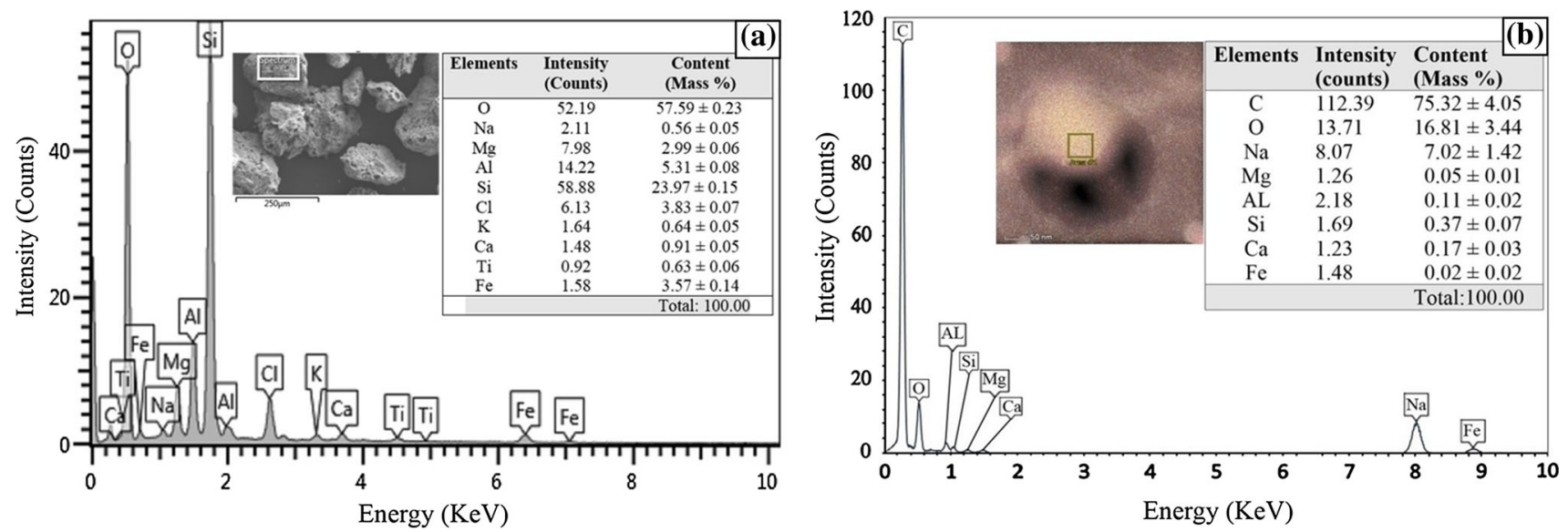

Figure 7 a SEM/EDX elemental analysis of HCl-purified BC compositions. b TEM/EDX composition elemental analysis of 15 wt $\%$ CA solution with $5 \mathrm{wt} \% \mathrm{BC} / \mathrm{CA}$ loading rate.
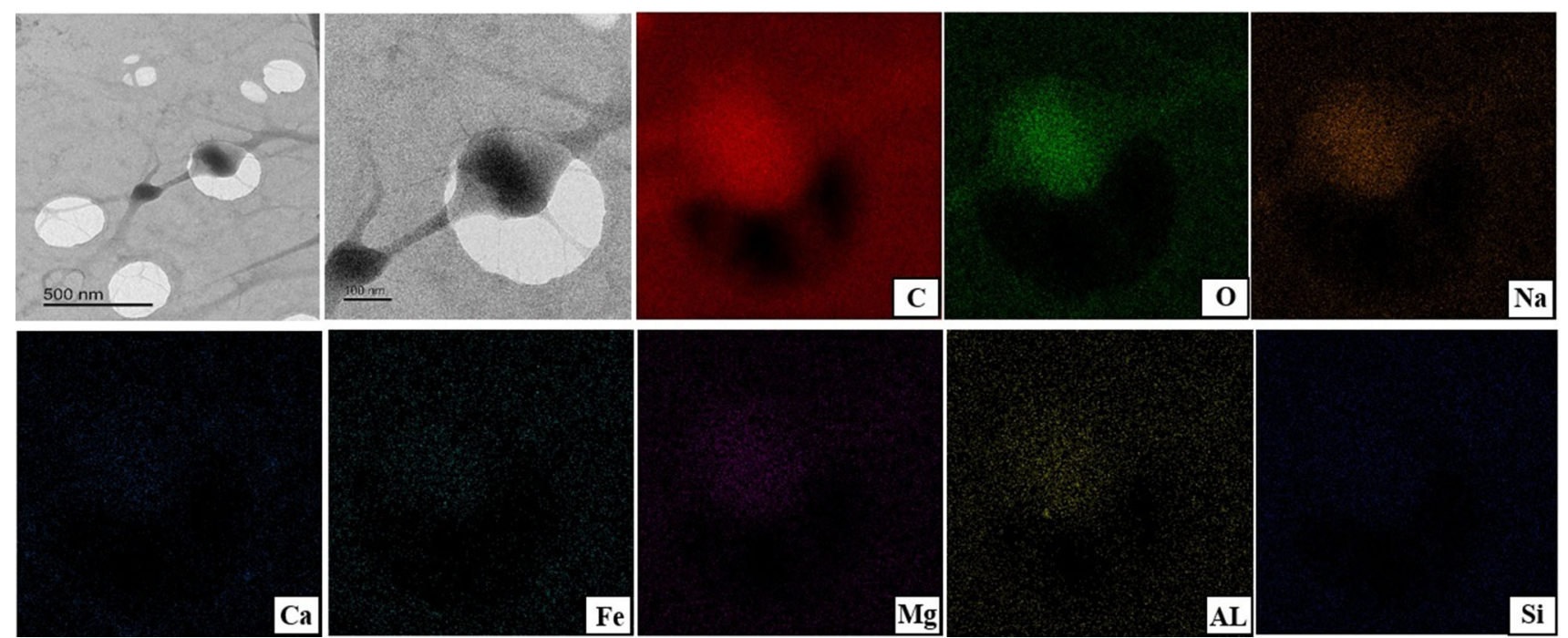

Figure 8 TEM images of $15 \mathrm{wt} \%$ CA solution with $10 \mathrm{wt} \%$ BC/CA loading and mapping images showing the existence of BC layers, composed of $\mathrm{C}, \mathrm{O}, \mathrm{Na}, \mathrm{Ca}, \mathrm{Fe}, \mathrm{Mg}, \mathrm{AL}$ and $\mathrm{Si}$ within the $\mathrm{CA} / \mathrm{BC}$ composite nanofibres.

$34.85 \pm 0.5 \mathrm{mN} \mathrm{m}^{-1}$ for CA15BC5 and to $32.35 \pm 0.45 \mathrm{mN} \mathrm{m}^{-1}$ for CA15BC0. It has been observed that there is a direct correlation between the uniformity of fibre diameter, polymer solution viscosity and surface tension [85]. The SEM image in Fig. $5 \mathrm{~d}-\mathrm{f}$ clearly reveals the formation of beaded structures and the aggregation of BC as its concentration increased. SEM images clearly revealed that beaded nanofibres and agglomerated BC formed if the surface tension and viscosity were too high. It has been reported that the $\mathrm{AcOH}$ concentration in water strongly affects the surface tension, and it can be reduced by increasing the $\mathrm{AcOH}$ concentration in water [86].

Electrical conductivity as a function of frequency is presented in Fig. 9c, for samples of dissolved CA at a concentration of $15 \%(\mathrm{w} / \mathrm{v})$ and $\mathrm{CA} / \mathrm{BC}$ at various $\mathrm{BC}$ loadings. The value of the electrical conductivity at the lowest measured nearly zero frequency has been considered as a direct current (DC) conductivity for comparative purpose which suits the case of the DC high-voltage power supply used in our work. However, Fig. 9c reveals that electrical conductivity increases as the frequency increases. Therefore, differences between all dissolved CA/BC solutions 

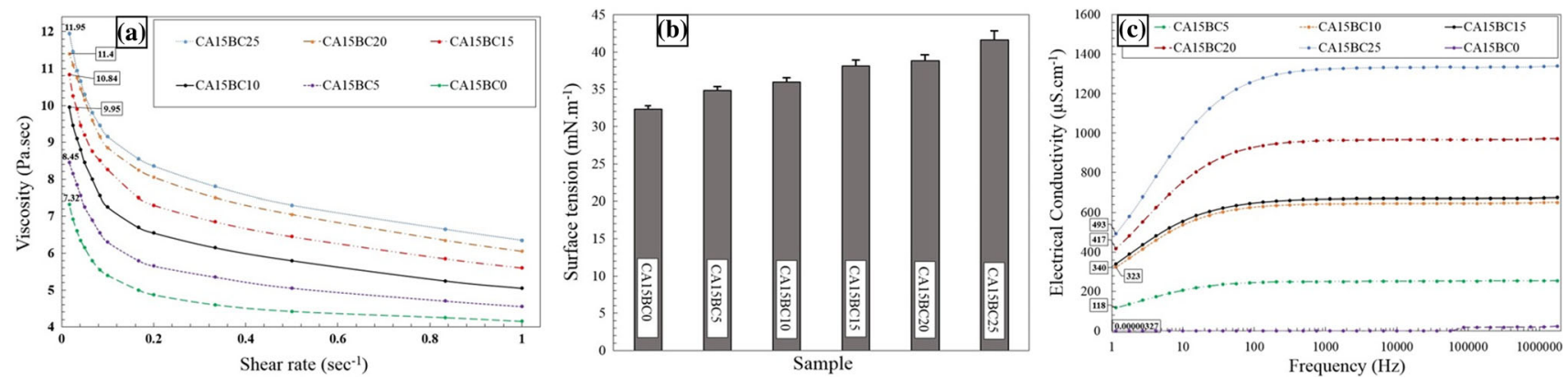

Figure 9 a Viscosity measurements as a function of shear rate, b averaged values of surface tension, c electrical conductivity measurements as a function of frequency for electrospun

were assessed at the lowest frequency $(1.0 \mathrm{~Hz}$, nearly zero). For the dissolved $\mathrm{CA} / \mathrm{BC}$ at various $\mathrm{BC}$ concentrations, the electrical conductivity increased as the $\mathrm{BC}$ concentration increased. For example, the electrical conductivity increases from 0.00000327 $\mu \mathrm{S} \mathrm{cm} \mathrm{cm}^{-1}$ (nearly zero) for CA15BC0 to $118 \mu \mathrm{S} \mathrm{cm}-1$ for CA15BC5 and to $493 \mu \mathrm{S} \mathrm{cm}{ }^{-1}$ for CA15BC25. It is clear that with the increasing $\mathrm{BC}$ concentration, the charge density of the $\mathrm{CA} / \mathrm{BC}$ solution increased. As a matter of fact, the electrical conductivity of the polymer solution mirrors the charge density on the jet and thus the higher elongation forces that are imposed on the fibres during spinning subject to the applied electrical field, leading to smaller fibre diameters.

\section{Structure and thermal properties of CA/BC composite nanofibrous fabrics}

Figure 10 shows the wide-angle $\mathrm{X}$-ray diffraction (WAXD) patterns of purified and activated $B C$, CA15BC0, CA15BC5 and CA15BC10 composite nanofibrous fabrics to indicate the distribution of $B C$ layers in the CA/BC composites. The XRD pattern of purified and activated $\mathrm{BC}$ shows one intense diffraction peak around about $2 \theta=27.2^{\circ}$ due to quartz which tends to form the highest peak. This peak indicates the distance between the adjacent $\mathrm{BC}$ lamellar structure, being approximately $2 \theta=27.2^{\circ}$, $d=15.62 \mathrm{~A}^{\circ}(1.562 \mathrm{~nm})$ according to Bragg's law. The other low-intensity peaks indicate that the $\mathrm{BC}$ is enriched with amorphous phases [82]. The XRD pattern of electrospun CA15BC0 nanofibres shows broad weak diffraction peaks at approximately $2 \theta=9.4^{\circ}$ and $2 \theta=44.8^{\circ}$ which are associated with the principal characteristic of the semi-crystalline
CA15BC0 nanofibres, CA15BC5, CA15BC10, CA15BC15, CA15BC20 and CA15BC25 composite nanofibres.

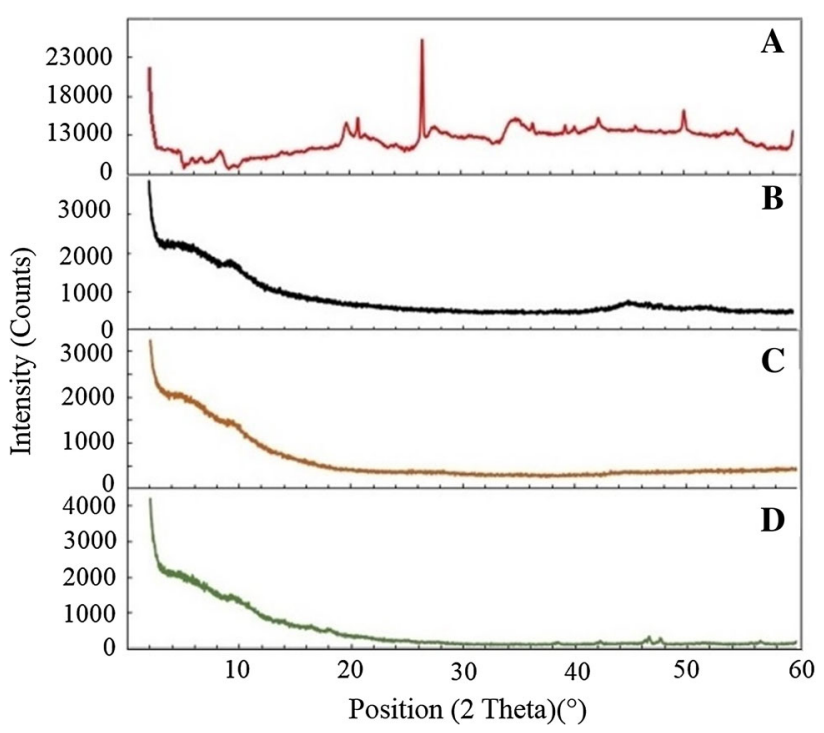

Figure 10 WAXD of $\mathrm{BC}$ (a) and $\mathrm{CA} 15 \mathrm{BC} 0$ (b), CA15BC5 (c) and $\mathrm{CA} 15 \mathrm{BC} 10$ (d) composite nanofibres.

acetylated structure of cellulose acetate [87]. The absence of BC peaks from the XRD patterns of CA15BC5 and CA15BC10 composites confirmed that most of the $\mathrm{BC}$ had been exfoliated, delaminated and dispersed in the CA nanofibrous fabric [24]. However, XRD pattern of CA15BC10 shows two diffraction peaks with low intensity at $2 \theta=47.8^{\circ}$ and $2 \theta=46.8^{\circ}$, which could be an indicator of partly stuffing of $\mathrm{BC}$ within the CA composites.

The thermal stability and behaviour of the purified and activated clay (BC) and electrospun CA/BC nanofibres were evaluated using TGA and DSC in a nitrogen atmosphere. Figure 11 shows the TGA thermograms of $\mathrm{BC}, \mathrm{CA} 15 \mathrm{BC} 0$ nanofibres and CA15BC5 and CA15BC10 composite nanofibres. As shown in Fig. 11, the thermal stability of $\mathrm{BC}$ is high; hence, only $17.67 \mathrm{wt} \%$ of $\mathrm{BC}$ is decomposed at $600{ }^{\circ} \mathrm{C}$. 
The TGA curves of CA and CA/BC fabrics manifest three phases of degradation which are different in comparison with pure BC which has nearly linear degradation rate. Table 3 shows the values of the yield of charred residue wt $\%$ at $600{ }^{\circ} \mathrm{C}$ and decomposition temperature at the onset and at $20 \%$ degradation rate of pure $\mathrm{BC}$ and $\mathrm{CA} 15 \mathrm{BC} 0, \mathrm{CA} 15 \mathrm{BC} 5$ and CA15BC10 fabrics. Generally, the initial weight loss from 40 to $120{ }^{\circ} \mathrm{C}$ is considered due to the evaporation of the absorbed water and the organic solvent $(\mathrm{AcOH})$ trapped in the composite nanofibres and between the clay layers [14]. The onset degradation (nearly $4 \mathrm{wt} \%$ weight loss) of CA/BC fabrics reduced from $240{ }^{\circ} \mathrm{C}$ for the CA15BC0 nanofibres to $230{ }^{\circ} \mathrm{C}$ for the $\mathrm{CA} 15 \mathrm{BC} 5$ nanofibres and $220^{\circ} \mathrm{C}$ for the CA15BC10 nanofibres. In addition, the decomposition temperatures at $20 \%$ degradation rate were $272{ }^{\circ} \mathrm{C}$ for the $\mathrm{CA} 15 \mathrm{BC} 0$ nanofibres and 249 and $237^{\circ} \mathrm{C}$ for $\mathrm{CA} 15 \mathrm{BC} 5$ and $\mathrm{CA} 15 \mathrm{BC} 10$, respectively. These reductions in the onset degradation and at $20 \%$ degradation rate temperatures were explained that the alkylammonium cations of clay were thermally unstable and decomposed at lower temperatures [24]. It is worth noting that the adsorption of alkylammonium cations from aqueous solution by montmorillonite has been occurred through an exchange

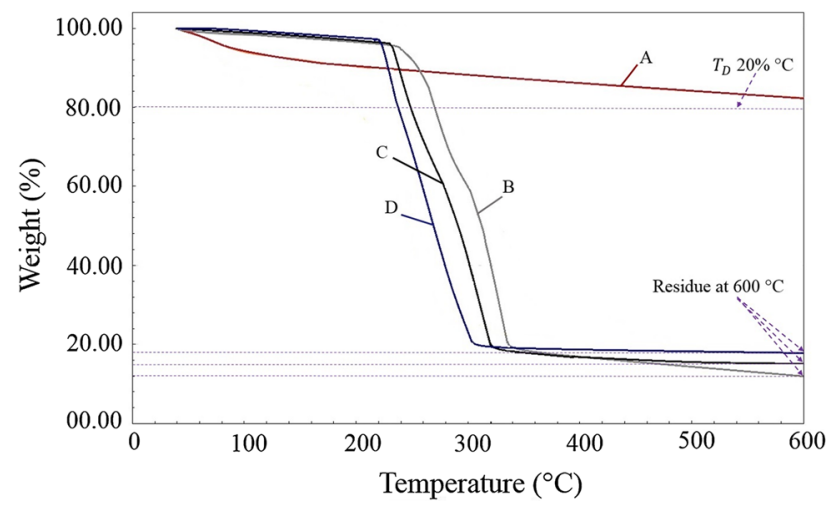

Figure 11 TGA thermograms of purified and activated $\mathrm{BC}(a)$, CA15BC0 nanofibres (b) and CA15BC5 (c) and CA15BC10 (d) composite nanofibres. reaction between the inorganic cations on the clay and the alkylammonium ions in the aqueous $(\mathrm{AcOH}$ $(75: 25, \mathrm{v} / \mathrm{v}))$ solution [88]. In the second phase, significant weight loss was observed due to thermal degradation. For CA15BC0 nanofibres, nearly $75 \%$ of the sample degraded from 245 to $350{ }^{\circ} \mathrm{C}$. This wide temperature range to the molten phase is due to the large amorphous region. After polymer dissolution and electrospinning, the internal structure of the electrospun and native materials differs. The area of the amorphous region increases, and the total crystallisation area decreases [89]. On the other hand, from the yield of charred residue data at $600{ }^{\circ} \mathrm{C}$, an improvement in the thermal stability can be proved when BC loading is increased. For instance, the yield of charred residue after thermal decomposition at $600{ }^{\circ} \mathrm{C}$ is increased from $11.96 \mathrm{wt} \%$ for the CA15BC0 nanofibres to $15.12 \mathrm{wt} \%$ for the CA15BC5 nanofibres and $18.06 \mathrm{wt} \%$ for the CA15BC10 nanofibres. In other words, the TGA curves distinctly indicate that the thermal stability of CA nanofibres is enhanced by increasing the loading of the $\mathrm{BC}$ which acts as a superior insulator and mass transport barrier resulting in oxygen and heat permeability reductions in the $\mathrm{CA} / \mathrm{BC}$ matrix during the heating exposure $[14,24,90]$.

Figure 12 shows the DSC curves of BC and CA/BC composite nanofibrous fabrics. It can be found from Fig. 12a that the DSC curve of BC showed one endothermic heat peak at $91.35{ }^{\circ} \mathrm{C}$ due to loss of adsorbed water [91]. Figure $12 \mathrm{~b}$ presents the DSC thermogram of CA which shows an endothermic heat peak located at $83.84{ }^{\circ} \mathrm{C}$ due to outflow and evaporation of the absorbed water [92]. In addition, an endothermic heat peak occurred at $362.48{ }^{\circ} \mathrm{C}$ which is attributed to the melting of the semi-crystalline regions and degradation of CA material. The endotherm of fusion for electrospun cellulose acetate nanofibres located at approximately $360{ }^{\circ} \mathrm{C}$ indicates their semi-crystalline character shown by the WAXD diffraction patterns which refer to the contributions of the amorphous and semi-crystalline regions. These
Table 3 The residue $\%$ at $600{ }^{\circ} \mathrm{C}$ and decomposition temperature at the onset and at $20 \%$ degradation rate of purified and activated $\mathrm{BC}$ and $\mathrm{CA} / \mathrm{BC}$ electrospun nanofibres

\begin{tabular}{llll}
\hline Materials & $\boldsymbol{T}_{\mathbf{D}}$ Onset $\left({ }^{\circ} \mathrm{C}\right)$ & $\boldsymbol{T}_{\mathbf{D}} 20 \%\left({ }^{\circ} \mathrm{C}\right)$ & Residue at $600{ }^{\circ} \mathrm{C}(\%)$ \\
\hline Purified and activated BC & - & - & 82.33 \\
CA15BC0 & 240 & 272 & 11.96 \\
CA15BC5 & 230 & 249 & 15.12 \\
CA15BC10 & 220 & 237 & 18.06 \\
\hline
\end{tabular}


results are in agreement with the published work of thermal properties of electrospun cellulose acetate nanofibres by Zahedi et al. [93]. It is also observed that the melting peak temperature of CA15BC5 is around $378.88{ }^{\circ} \mathrm{C}$ and the melting peak temperature of CA15BC10 is at $401.18{ }^{\circ} \mathrm{C}$, which both are slightly higher than that of the neat CA electrospun nanofibres. It was also observed that higher values of enthalpy of crystallisation and fusion were found for CA15BC5 and CA15BC10 samples as shown in Fig. 12c, d. Therefore, this indicates that the $B C$ layers are existent in $\mathrm{CA} / \mathrm{BC}$ nanofibres and also make these composite nanofibres more thermally stable.

\section{Future perspectives and outlook}

Nanofibrous membranes incorporating accessible adsorbents are believed to be an efficient structure for pressure-driven membrane-selection processes. Nanofibrous membranes have significant advantages over reverse osmosis membranes, including low operating pressure and high permeate flux [2]. The gradual degradation of CA nanofibre surfaces is likely to create diffusion channels that can be expected to promote adsorption of organic pollutants and

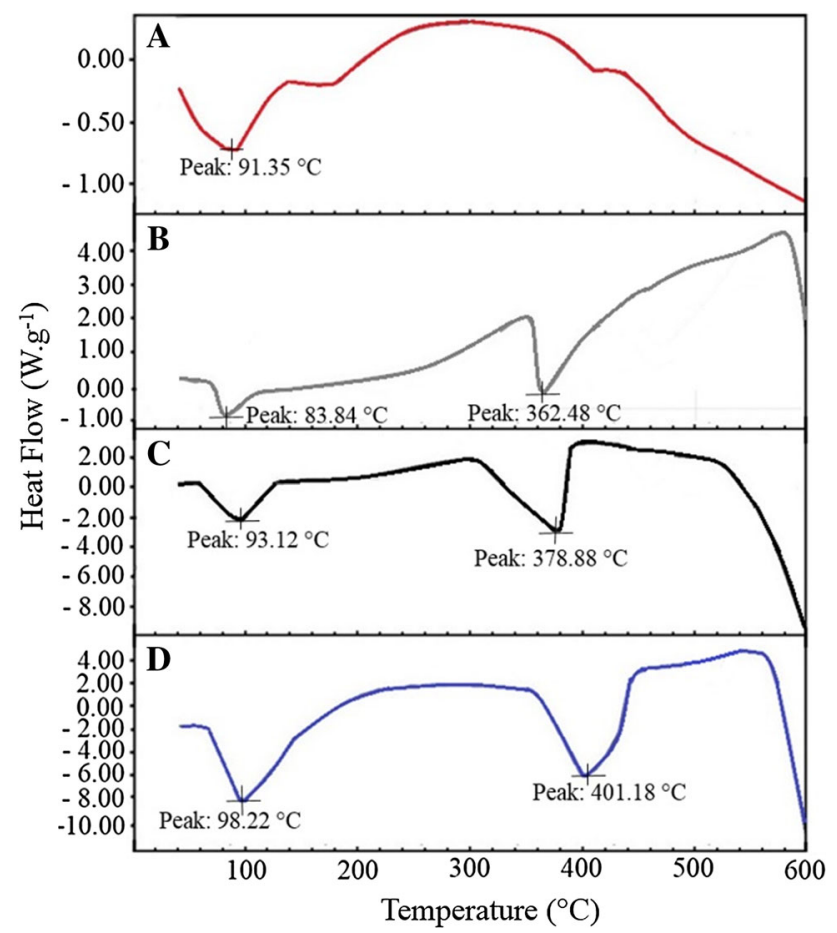

Figure 12 DSC thermograms of purified and activated BC (a), CA15BC0 nanofibres (b) and $\mathrm{CA} 15 \mathrm{BC} 5$ (c) and $\mathrm{CA} 15 \mathrm{BC} 10$ (d) composite nanofibres. heavy metal ions with higher mass transfer and efficiency. This is an area for further study.

\section{Conclusion}

A comprehensive review of electrospun nanofibres containing MMT as fillers and their proposed applications highlighted a significant focus on materials containing synthesised rather than naturally occurring MMTs. Herein, natural $\mathrm{BC}$ was investigated as a loading component in the manufacture of $\mathrm{CA}$ nanofibre webs. The natural BC was dried, crushed, ground and sieved prior to before being purified with $\mathrm{HCl}$ and activated with $\mathrm{Na}_{2} \mathrm{CO}_{3}$. CMC was used to aid dispersion and suspension of $\mathrm{BC}$ prior to the production of BC-loaded CA nanofibre webs using free surface electrospinning. Optimal nanospider electrospinning parameters for $\mathrm{CA} / \mathrm{BC}$ were $65-75 \mathrm{kV}$ and $12 \mathrm{~cm}$ for applied voltage and electrospinning working distance, respectively. SEM images showed that all nanofibres were randomly distributed and interpenetrated jellyfish-like semispherical features containing BC particles when the BC loadings were of 5-10 wt $\%$. TEM confirmed that BC particles of different sizes and shapes were contained within these spatially distributed jellyfish-like features. When the $\mathrm{BC}$ loading increased to more than $15 \mathrm{wt} \%$, nonuniform/beaded CA/BC fabrics were formed. Electrospinning appears to play a role in reducing the particle size of natural $\mathrm{BC}$ due to the electrostatic forces, which means that pre-refining of natural $\mathrm{BC}$ to the final required particle size prior to free surface electrospinning is not necessary. In this work, it has been demonstrated that up to $10 \mathrm{wt} \%$ natural BC can be incorporated in CA nanofibre webs using an electrospinning process that is already available at industrial scale.

\section{Acknowledgements}

The authors wish to thank the University of Leeds for financial support. Dr. Emily James in the School of Chemical and Process Engineering and Dr. Daniel Baker in the School of Physics and Astronomy at the University of Leeds are gratefully acknowledged for technical assistance with the surface tension and electrical conductivity measurements. 


\section{Compliance with ethical standards}

Conflict of interest All the authors declare that they have no conflict of interest.

Open Access This article is distributed under the terms of the Creative Commons Attribution 4.0 International License (http://creativecommons.org/ licenses/by/4.0/), which permits unrestricted use, distribution, and reproduction in any medium, provided you give appropriate credit to the original author(s) and the source, provide a link to the Creative Commons license, and indicate if changes were made.

\section{References}

[1] Bazbouz MB, Stylios GK (2008) Alignment and optimisation of nylon 6 nanofibres by electrospinning. J Appl Polym Sci 107(5):3023-3032

[2] Malwal D, Gopinath P (2016) Fabrication and applications of ceramic nanofibres in water remediation: a review. Crit Rev Environ Sci Technol 46(5):500-534

[3] Sattar R, Kausar A, Siddiq M (2015) Advances in thermoplastic polyurethane composites reinforced with carbon nanotubes and nanofibres: a review. J Plast Film Sheeting 31(2):186-224

[4] Hu J, Kai D, Ye H, Tian L, Ding X, Ramakrishna S (2017) Electrospinning of poly (glycerol sebacate) based nanofibres for nerve tissue engineering. Mater Sci Eng C 70:1089-1094

[5] Li D, Xia Y (2004) Electrospinning of nanofibres: reinventing the wheel. Adv Mater 16:1151-1170

[6] Su Z, Ding J, Wei G (2014) Electrospinning: a facile technique for fabricating polymeric nanofibres doped with CNT and metallic nanoparticles for sensor applications. RSC Adv 4:52598-52610

[7] Bazbouz MB, Stylios GK (2010) The tensile properties of electrospun nylon 6 single nanofibres. J Polym Sci (B) Polym Phys 48(15):1719-1731

[8] Fong H, Liu W, Wang CS, Vai RA (2002) Generation of electrospun fibres of nylon 6 and nylon 6-montmorillonite nanocomposite. Polymer 43(3):775-780

[9] Li L, Bellan LM, Craighead HG, Frey MW (2006) Formation and properties of nylon- 6 and nylon-6/montmorillonite composite nanofibres. Polymer 47:6208-6217

[10] Li Q, Wei Q, Wu N, Cai Y, Gao W (2008) Structural characterisation and dynamic water adsorption of electrospun polyamide6/montmorillonite nanofibres. J Appl Polym Sci 107:3535-3540
[11] Cai Y, Huang F, Wei Q, Wu E, Gao W (2008) Surface functionalisation morphology and thermal properties of polyamide6/O-MMT composite nanofibres by $\mathrm{Fe}_{2} \mathrm{O}_{3}$ sputter coating. Appl Surf Sci 254:5501-5505

[12] Cai Y, Huang F, Wei Q, Song L, Hu Y, Ye Y, Xu Y, Gao W (2008) Structure, morphology, thermal stability and carbonisation mechanism studies of electrospun PA6/Fe-OMT nanocomposite fibres. Polym Degrad Stab 93:2180-2185

[13] Cai Y, Li Q, Wei Q, Wu Y, Song L, Hu Y (2008) Structures, thermal stability, and crystalline properties of polyamide6/ organic-modified Fe-montmorillonite composite nanofibres by electrospinning. J Mater Sci 43:6132-6138. https://doi. org/10.1007/s10853-008-2921-6

[14] Li Q, Gao D, Wei Q, Ge M, Liu W, Wang L, Hu K (2010) Thermal stability and crystalline of electrospun Polyamide 6/Organo-Montmorillonite nanofibres. J Appl Polym Sci 117:1572-1577

[15] Cai Y, Wu N, Wei Q, Xu Q, Gao W, Song L, Hu Y (2008) Structure, surface morphology, thermal and flammability characterisations of polyamide 6/organic-modified $\mathrm{Fe}$ montmorillonite nanocomposite fibres functionalised by sputter coating of silicon. Surf Coat Technol 203:264-270

[16] Agarwal A, Raheja A, Natarajan TS, Chandra TS (2014) Effect of electrospun montmorillonite-nylon 6 nanofibrous membrane coated packaging on potato chips and bread. Innov Food Sci Emerg Technol 26:424-430

[17] Wu H, Krifa M, Koo JH (2014) Flame retardant polyamide 6/nanoclay/intumescent nanocomposite fibres through electrospinning. Tex Res J 84(10):1106-1118

[18] Beatrice CAG, Santos CRD, Branciforti MC, Bretas RES (2012) Nanocomposites of polyamide 6/residual monomer with organic-modified montmorillonite and their nanofibres produced by electrospinning. Mater Res 15(4):611-621

[19] Yu T, Lin J, Xu J, Chen T, Lin S (2005) Novel polyacrylonitrile nanocomposites containing Na-montmorillonite and nano $\mathrm{SiO}_{2}$ particle. Polymer 46:5695-5697

[20] Qiao H, Cai Y, Chen F, Wei Q, Weng F, Huang F, Song L, $\mathrm{Hu}$ Y, Gao W (2009) Influences of organic-modified Femontmorillonite on structure, morphology and properties of polyacrylonitrile nanocomposite fibres. Fibres Polym 10(6):750-755

[21] Shami Z, Sanjani NS (2010) The role of Na-montmorillonite on thermal characteristics and morphology of electrospun PAN nanofibres. Fibres Polym 11(5):695-699

[22] Wang Q, Li G, Zhang J, Huang F, Lu K, Wei Q (2014) PAN nanofibres reinforced with MMT/GO hybrid nanofillers. J Nanomater 2014:298021

[23] Almuhamed S, Bonne M, Khenoussi N, Brendle J, Schacher L, Lebeau B, Adolphe DC (2016) Electrospinning composite 
nanofibres of polyacrylonitrile/synthetic Na-montmorillonite. J Indus Eng Chem 35:146-152

[24] Kim SW, Han SO, Sim N, Cheon JY, Park WH (2015) Fabrication and characterisation of cellulose acetate/montmorillonite composite nanofibres by electrospinning. J Nanomater 2015:275230

[25] Mingyu JZ, Wang SX, Wu J, Yang Z, Cao J, Chen Y, Wei Q (2016) Preparation of a cellulose acetate/organic montmorillonite composite porous ultrafine fibre membrane for enzyme immobilisation. J Appl Polym Sci 133(33): 43818-43825

[26] Kalaoglu O, Unlu CH, Atici OG (2016) Synthesis, characterisation and electrospinning of corn cellulose-graft-polyacrylonitrile and their clay nanocomposites. Carbohydr Polym 147:37-44

[27] Cai J, Lei M, Zhang Q, He JR, Chen T, Liu S, Fu SH, Li TT, Fei P (2017) Electrospun composite nanofibre mats of cellulose@ organically modified montmorillonite for heavy metal ion removal: design, characterisation, evaluation of absorption performance. Composites (A) 92:10-16

[28] Lee HW, Karim MR, Ji HM, Choi JH, Gim HD, Park SM, Weontae O, Yeum JH (2009) Electrospinning fabrication and characterisation of poly (vinyl alcohol)/montmorillonite nanofibre mats. J Appl Polym Sci 113:1860-1867

[29] Ji HM, Lee HW, Karim MR, Cheong IW, Bae EA, Kim TH, Islam MS, Ji BC, Yeum H (2009) Electrospinning and characterisation of medium molecular weight poly(vinyl alcohol)/high-molecular-weight poly (vinyl alcohol)/montmorillonite nanofibres. Colloid Polym Sci 287:751-758

[30] Park JH, Karim MR, Kim IK, Cheong IW, Kim JW, Bae DG, Cho JW, Yeum JH (2010) Electrospinning fabrication and characterisation of poly (vinyl alcohol)/montmorillonite/silver hybrid nanofibres for antibacterial applications. Colloid \& Polym Sci 288:115-121

[31] Liu YL, Li Y, Xu JT, Fan ZQ (2010) Cooperative effect of electrospinning and nanoclay on formation of polar crystalline phases in poly (vinylidene fluoride). ACS Appl Mater Interfaces 2:1759-1768

[32] Lopes AC, Ferreira JCC, Costa CM, Mendez SL (2013) Crystallisation kinetics of montmorillonite/poly (vinylidene fluoride) composites and its correlation with the crystalline polymer phase formation. Thermochim Acta 574:19-25

[33] Fang C, Yang S, Zhao X, Du P, Xiong J (2016) Electrospun montmorillonite modified poly(vinylidene fluoride) nanocomposite separators for lithium-ion batteries. Mater Res Bull 79:1-7

[34] Hong JH, Jeong EH, Lee HS, Baik DH, Seo SW, Youk JH (2005) Electrospinning of polyurethane/organically modified montmorillonite nanocomposites. J Polym Sci B Polym Phys $43: 3171-3177$
[35] Saha K, Butola BS, Joshi M (2014) Drug-Loaded polyurethane/clay nanocomposite nanofibres for topical drugdelivery application. J Appl Polym Sci 131(10): 40230-40238

[36] Ortenzi MA, Basilissi L, Farina H, Silvestro GD, Piergiovanni L, Mascheroni E (2015) Evaluation of crystallinity and gas barrier properties of films obtained from PLA nanocomposites synthesised via "in situ" polymerisation of L-lactide with silane-modified nanosilica and montmorillonite. Eur Polym J 66:478-491

[37] Lee YH, Lee JH, An IG, Kim C, Lee DS, Lee YK, Nam JD (2005) Electrospun dual-porosity structure and biodegradation morphology of Montmorillonite reinforced PLLA nanocomposite scaffolds. Biomaterials 26:3165-3172

[38] Kishimoto Y, Ito F, Usami H, Togawa E, Tsukada M, Morikawa H, Yamanaka S (2013) Nanocomposite of silk fibroin nanofibre and montmorillonite: fabrication and morphology. Int J Biol Macromol 57:124-128

[39] Chen X, Gao H, Ploehn HJ (2014) Montmorillonite- levan nanocomposites with improved thermal and mechanical properties. Carbohydr Polym 101:565-573

[40] Ayutthaya SIN, Tanpichai S, Sangkhun W, Wootthikanokkhan J (2016) Effect of clay content on morphology and processability of electrospun keratin/poly (lactic acid) nanofibre. Int J Biol Macromole 85:585-595

[41] Islam MS, Yeum JH, Das AK (2012) Effect of pullulan/poly (vinyl alcohol) blend system on the montmorillonite structure with property characterisation of electrospun pullulan/ poly(vinyl alcohol)/montmorillonite nanofibres. J Colloid Interface Sci 368:273-281

[42] Islam MS, Rahaman MS, Yeum JH (2015) Electrospun novel super-absorbent based on polysaccharide-polyvinyl alcohol-montmorillonite clay nanocomposites. Carbohydr Polym 115:69-77

[43] Ma Y, Li LB, Gao GX, Yang XY, You Y (2016) Effect of montmorillonite on the ionic conductivity and electrochemical properties of a composite solid polymer electrolyte based on polyvinylidenedifluoride/polyvinyl alcohol matrix for lithium ion batteries. Electrochim Acta 187:535-542

[44] Park JH, Lee HW, Chae DK, Oh W, Yun JD, Deng Y, Yeum JH (2009) Electrospinning and characterisation of poly (vinyl alcohol)/chitosan oligosaccharide/clay nanocomposite nanofibres in aqueous solutions. Colloid Polym Sci 287:943-950

[45] Bunyatova U, Rzayev ZMO, Şimşek M (2016) Multifunctional e-spun colloidal nanofibre structures from various dispersed blends of PVA/ODA-MMT with PVP/ODAMMT, poly (VP-alt-MA) and AgNPs incorporated polymer complexes as electro-active platforms. Express Polym Lett 10(7):598-616 
[46] Simsek M, Rzayev ZMO, Acar S, Salamov B, Bunyatova U (2016) Novel colloidal nanofibre electrolytes from PVAorganoclay/poly(MA-ALT-MVE), and their $\mathrm{NaOH}$ and Agcarrying polymer complexes. Polym Eng Sci 56(2):204-213

[47] Simsek M, Rzayev ZMO, Bunyatova U (2016) Multifunctional electroactive electrospun nanofibre structures from water solution blends of PVA/ODA-MMT and poly (Maleic acid-ALT-Acrylic acid): effects of Ag, organoclay, structural rearrangement and $\mathrm{NaOH}$ doping factors. Adv Natural Sci Nanosci Nano-technol 7(2):025009-025013

[48] Rzayev ZMO, Simsek M, Bunyatova U, Salamov B (2016) Novel colloidal nanofibre semiconductor electrolytes from solution blends of PVA/ODA-MMT, poly (itaconicanhydride-alt-2-vinyl-1, 3-dioxalan) and its Ag-carrying polymer complex by reactive electrospinning. Colloids Surfaces A Physicochem Eng Aspects 492:26-37

[49] Wang M, Hsieh AJ, Rutledge GC (2005) Electrospinning of poly (MMA-co-MAA) copolymers and their layered silicate nanocomposites for improved thermal properties. Polymer 46:3407-3418

[50] Rzayev MO, Simsek M, Salimi K (2015) Functional copolymer/organo-MMT Nanoarchitectures: fabrication and characterisation of electrospun nanofibres from PCL/ODAMMT and copolymer-g-PLA/Ag-MMT blends. Polym-Plast Technol Eng 54:1723-1734

[51] Rzayev ZMO, Erdonmez D, Erkan K, Bunyatova MU (2015) Functional copolymer/organo-MMT nano-architectures. XXII. Fabrication and characterisation of antifungal and antibacterial poly (Vinyl Alcohol-co-Vinyl Acetate/ ODA-MMT/AgNPs nanofibres and coatings by e-spinning and c-spinning methods. Int J Polym Mater Polym Biomater 64:267-278

[52] Kalgaonkar RA, Jog JP (2007) Polyolefin/Clay Nanocomposites. In: Brown PJ, Stevens K (eds) Nanofibres and nanotechnology in textiles. Woodhead publishing Ltd, Cambridge, pp 351-385

[53] Haydel SE, Remenih CM, Williams LB (2008) Broadspectrum in vitro antibacterial activities of clay minerals against antibiotic-susceptible and antibiotic-resistant bacterial pathogens. J Antimicrob Chemother 61:353-361

[54] Marini M, Bondi M, Iseppi R, Toselli M, Pilati F (2007) Preparation and antibacterial activity of hybrid materials containing quaternary ammonium salts via sol-gel process. Euro Polym J 43:3621-3628

[55] Williams LB, Haydel SE (2010) Evaluation of the medicinal use of clay minerals as antibacterial agents. Int Geol Rev 52(7/8):745-770

[56] Carretero MI (2002) Clay minerals and their beneficial effects upon human health. A review. Appl Clay Sci 21:155-163
[57] Carretero MI, Lagaly G (2007) Clays and health: an introduction. Appl Clay Sci 36:1-3

[58] Gomes CF, Silva JP (2007) Minerals and clay minerals in medical geology. Appl Clay Sci 36:4-21

[59] Al-Jlil S (2010) Removal of heavy metals from industrial wastewater by adsorption using local bentonite clay and roasted date pits in Saudi Arabia. Trends Appl Sci Res 5:138-145

[60] Zohra M, Rose J, Borschneck D (2014) Urban wastewater treatment by adsorption of organic matters on modified bentonite by Iron-Aluminum. J Encapsul Adsorp Sci 4:71-79

[61] Bleifuss RL (1973) Activation of non-swelling bentonite. Clay Miner 10:41-55

[62] Alther GR (1982) The role of bentonite in soil sealing applications. Bull Assoc Eng Geol 19(4):401-409

[63] Dosunmu OO, Chase GG, Kataphinan W, Reneker DH (2006) Electrospinning of polymer nanofibres from multiple jets on a porous tubular surface. Nanotechnology 17:1123-1127

[64] Reneker H, Yarin AL, Fong H, Koombhongse S (2000) Bending instability of electrically charged liquid jets of polymer solutions in electrospinning. J Appl Phys $87: 4531-4547$

[65] Bazbouz MB (2009) An investigation of yarn spinning from electrospun nanofibres, PhD Thesis, Heriot Watt University, United Kingdom, URI: http://hdl.handle.net/10399/2245

[66] Formhals A (1944) Method and apparatus for spinning. US Patent 2349950

[67] Jirsak O, Sanetrnik F, Lukas D, Kotek V, Martinova L, Chaloupek J (2005) A method of nanofibres production from a polymer solution using electrostatic spinning and a device for carrying out the method. World Intellectual Property Organization Patent WO024101

[68] The Elmarco company (2018) http://elmarco.com. Accessed 09 Jan 2018

[69] Forward KM, Rutledge GC (2012) Free surface electrospinning from a wire electrode. Chem Eng J 183(15):492-950

[70] Park HM, Liang X, Mohanty AK, Misra M, Drzal LT (2004) Effect of compatibilizer on nanostructure of the biodegradable cellulose acetate/clay nanocomposites. Macromolecules 37(24):9076-9082

[71] Konwarh R, Karak N, Misra M (2013) Electrospun cellulose acetate nanofibres: the present status and gamut of biotechnological applications. Bio-technol Adv 31(4):421-437

[72] Evans EH (1998) An introduction to analytical atomic spectrometry. Wiley, Chichester, pp 164-175

[73] Gaydon AG, Wolfhard HG (1960) Flames: their structure, radiation and temperature. Chapman \& Hall, London, p 304 
[74] Juza J (1997) The pendant drop method of surface tension measurement: equation interpolating the shape factor tables for several selected planes. Czechoslovak J Phys 47(3):351-357

[75] Murray HH (1991) Some application of clay minerals. Appl Clay Sci 5:379-395

[76] Espinoza DN, Santamarina JC (2012) Clay interaction with liquid and supercritical $\mathrm{CO} 2$ : the relevance of electrical and capillary forces. Int J Greenhouse Gas Control 10:351-362

[77] Bendou S, Amrani M (2014) Effect of hydrochloric acid on the structural of sodic-bentonite clay. J Minerals Mater Character Eng 2:404-413

[78] Yildiz N, Sarikaya Y, Calimli A (1999) The effect of the electrolyte concentration, $\mathrm{pH}$ on the rheological properties of the original and the $\mathrm{Na}_{2} \mathrm{CO}_{3}$-activated Kutahya bentonite. Appl Clay Sci 14:319-327

[79] Volzone C, Garrido LB (1991) The effect of some physicochemical and mineralogical properties on the $\mathrm{Na}_{2} \mathrm{CO}_{3}$ activation of Argentine bentonites. Appl Clay Sci 6:143-154

[80] Pramanik S, Das G, Karak N (2013) Facile preparation of polyaniline nanofibres modified bentonite nanohybrid for gas sensor application. RSC Adv 3:4574-4581

[81] Kumar AS, Mahto V, Sharma V (2003) Behaviour of organic polymers on the rheological properties of Indian bentonite-water based drilling fluid system and its effect on formation damage. Indian J Chem Technol 10:525-530

[82] Masindi V (2017) Application of cryptocrystalline magnesite-bentonite clay hybrid for defluoridation of underground water resources: implication for point of use treatment. J Water Reuse Desalin 7:338-352

[83] Ghorani B, Goswami P, Russell SJ (2015) Parametric study of electrospun cellulose acetate in relation to fibre diameter. Res J Tex Apparel 19(4):24-40
[84] Sebastiani E, Lacquaniti L (1967) Acetic acid-water system thermodynamically correlation of vapour-liquid equilibrium data. Chem Eng Sci 22:1155-1162

[85] Demir MM, Yilgor I, Yilgor E, Erman B (2002) Electrospinning of polyurethane fibres. Polymer 43:3303-3309

[86] Vega C, De Miguel E (2007) Surface tension of the most popular models of water by using the test-area simulation method. J Chem Phys 126:154707-154710

[87] Hong CH, Ki SJ, Jeon JH, Che HL, Park IK, Kee CD, Oh IK (2013) Electroactive bio-composite actuators based on cellulose acetate nanofibres with specially chopped polyaniline nanoparticles through electrospinning. Compos Sci Technol 87:135-141

[88] Theng BKG, Greenland DJ, Quirk JP (1967) Adsorption of alkylammonium cations by montmorillonite. Clay Miner $7: 1-17$

[89] Qin X, Hui Wang H, Wu S (2011) Investigation on structure and thermal properties of electrospun cellulose diacetate nanofibres. J Industrial Tex 42(3):244-255

[90] Zhang J, Wilkie CA (2005) Fire retardancy of polyethylene alumina trihydrate containing clay as a synergist. Polym Adv Technol 16(7):549-553

[91] Abdou MI, Al-sabagh AM, Dardir MM (2013) Evaluation of Egyptian bentonite and nano-bentonite as drilling mud. Egypt J Pet 22:53-59

[92] VanderHart DL, Hyatt JA, Atalla RH, Tirumalai VC (1996) Solid-state 13C NMR and Raman studies of cellulose triacetate: oligomers, polymorphism, and inferences about chain polarity. Macromolecules 29:730-739

[93] Zahedi P, Rafie A, Wojczak E (2016) Morphological and thermal properties of optimised electrospun cellulose acetate nanofibres during deacetylation in different $\mathrm{pH}$ values. Indian J Fibre Tex Res 41:13-18 